\title{
Magmatism as a response to exhumation of the Priest River complex, northern Idaho: constraints from zircon $\mathrm{U}-\mathrm{Pb}$ geochronology and $\mathrm{Hf}$ isotopes
}

L. M. Stevens ${ }^{\mathrm{a}, *}$, J. A. Baldwin ${ }^{\mathrm{a}}$, J. L. Crowley ${ }^{\mathrm{b}}$, C. M. Fisher ${ }^{\mathrm{c}, 1}$, J. D. Vervoort ${ }^{\mathrm{c}}$

a Department of Geosciences, University of Montana, 32 Campus Drive \#1296, Missoula, Montana 59812-1296, USA

${ }^{\mathrm{b}}$ Department of Geosciences, Boise State University, 1910 University Drive, Boise, Idaho 83725-1535, USA

c School of the Environment, Washington State University, Pullman, WA 99164-2812, USA

${ }^{1}$ Present address: Department of Earth and Atmospheric Sciences, University of Alberta, Edmonton, Alberta, T6G 2E3, Canada

* Corresponding author at: Department of Geosciences, University of Montana, 32

Campus Drive \#1296, Missoula, Montana 59812-1296, USA. Email address: liane.stevens@umontana.edu 


\section{ABSTRACT}

Zircon and monazite $\mathrm{U}-\mathrm{Pb}$ geochronology and zircon $\mathrm{Hf}$ isotopes place constraints on the temporal and source relationships between crustal anatexis, magmatism, and exhumation of the Priest River metamorphic core complex, northern Idaho. Granitoids that intruded the migmatitic, pelitic Hauser Lake gneiss include the $<76.5 \pm 0.1$ Ma Spokane granite, $50.13 \pm 0.02$ Ma Silver Point quartz monzonite, c. 47.9 Ma Wrencoe granodiorite, $<46.4$ \pm 1.8 Ma Rathdrum granite, and a $<49.8 \pm 0.4$ Ma leucocratic dike. Cretaceous magmatism preceded the $c$. 64 Ma peak metamorphism (recorded by monazite) of the Hauser Lake gneiss, whereas discrete pulses of Eocene magmatic activity post-date the onset of exhumation by 10 Ma. The relative timing of pluton emplacement in the Priest River complex indicates that it was primarily a response to decompression rather than a cause. The mylonitized Silver Point and undeformed Wrencoe plutons bracket the end of a rapid phase of exhumation to $c$. 50-48 Ma. Zircon $\varepsilon_{\mathrm{Hf}(\mathrm{i})}$ values and Lu-Hf isotope evolution indicate that the Silver Point and Wrencoe plutons crystallized from homogeneous magmas sourced from Archean-Proterozoic basement orthogneisses, whereas the Spokane granite and two leucocratic units appear to have been produced by partial melting of the Hauser Lake gneiss. Comparison of the Priest River complex with other deeply exhumed northern Cordilleran complexes indicates variability in the timing and, therefore, relative influences of partial melting and magmatism on the initiation of exhumation, which must be accounted for in numerical models of metamorphic core complex formation and evolution. 
Keywords: Priest River complex; exhumation; magmatism; zircon; CA-TIMS; Hf isotopes 


\section{1. Introduction}

$2 \quad$ Partial melting and magmatism are spatially and temporally associated with

3 continental metamorphic core complexes in the North American Cordillera (e.g.,

4 Armstrong, 1982; Davis and Coney, 1979). The resulting decrease in crustal viscosity

5 and strength due to the presence of melt may initiate and/or enhance core complex

6 exhumation during gravitational collapse of thickened crust (e.g., Armstrong, 1982;

7 Armstrong and Ward, 1991; Coney and Harms, 1984; Foster and Fanning, 1997; Gans,

8 1989; House et al., 2002; Lister and Baldwin, 1993; Vanderhaeghe and Teyssier, 2001).

9 In order to assess the influence of partial melting and magmatism on exhumation of core

10 complexes, the timing of these processes must be well constrained. Variation in the

11 volume and timing of partial melting and magmatism among Cordilleran metamorphic

12 core complexes suggests that the influence of each on exhumation may vary (e.g.,

13 Armstrong, 1982; Whitney et al., 2013). Such differences must be either allowed or

14 accounted for in numerical models of metamorphic core complex formation and

15 evolution.

16 Core complexes within the northern North American Cordillera typically exhibit

17 greater degrees of partial melting and were exhumed during the Paleocene and Eocene,

18 whereas complexes of the southern belt display lesser degrees of partial melting and were

19 exhumed during the Oligocene and/or Miocene (Fig. 1; e.g., Armstrong, 1982; Coney,

20 1980; Coney \& Harms, 1984; Rey et al., 2009; Whitney et al., 2013). The northern belt

21 core complexes are also similar in position relative to the Sevier thrust front, craton

22 margin $\left({ }^{87} \mathrm{Sr} /{ }^{86} \mathrm{Sr}=0.706\right)$, and the compressional North American plate margin. This

23 study focuses on the northern belt complexes as examples of metamorphic core 
24 complexes with histories of partial melting and magmatism in a far-field compressional 25 tectonic setting.

26 The degree of partial melting in core complexes within the northern Cordillera

27 varies from the diatexite (melt-dominated) migmatites of the Shuswap complex gneiss

28 domes (e.g., Gordon et al., 2008; Norlander et al., 2002; Vanderhaeghe et al. 1999), to the

29 metatexite (lower melt fraction) migmatites of the Priest River complex (e.g., Stevens et

30 al., 2015), to migmatite-absent complexes, such as the Clearwater complex (e.g., Lang

31 and Rice, 1985) (Fig. 1). Similarly, magmatism varies in character, volume, and timing.

32 Leucogranite in the Thor-Odin dome within the Shuswap complex crystallized during

33 exhumation (Fig. 1; Vanderhaeghe et al., 1999). In the Priest River complex, granitoid

34 intrusions formed either well prior to peak metamorphism or following the onset of

35 extension (syn- to post-kinematic) (Fig. 1; Archibald et al., 1984; Bickford et al., 1985;

36 Doughty and Price, 1999; Harms and Price, 1992; Stevens et al., 2015; Whitehouse et al., 37 1992).

38 The Priest River complex (PRC) is located at the southern end of the Omineca

39 crystalline belt, the eastern metamorphic core of the Cordillera; the Shuswap complex is

40 also located within the Omineca Belt (Fig. 1; Parrish et al., 1988). The PRC, Shuswap,

41 Clearwater, and Bitterroot complexes were exhumed from similar depths ( 7-11 kbar, or

42 23-33 km) (Fig. 1; Doughty et al., 2007; Foster et al., 2001; House et al., 1997;

43 Norlander et al., 2002; Stevens et al., 2015). The PRC, along with the Shuswap and

44 Bitterroot complexes, is among the larger complexes in the northern belt (Fig. 1);

45 however, the Shuswap complex contains melt-dominated, vertically exhumed gneiss

46 domes (e.g., Gordon et al., 2008; Norlander et al., 2002), and the Bitterroot complex is 
47 dominated by the Idaho batholith and behaved as a gneiss dome (e.g., Chase et al., 1983;

48 Foster and Fanning, 1997; Hyndman, 1980). The PRC's shared characteristics with other

49 northern belt complexes, as well as its lesser degree of partial melting and late pluton

50 emplacement, suggest that it is a representative northern belt complex that will provide

51 constraints on the relative influences of crustal anatexis and plutonism on exhumation.

52 In order to characterize the relationships between partial melting, magmatism, and

53 exhumation in the PRC and other northern belt core complexes, two hypothetical end

54 member scenarios are presented here. In the first scenario, partial melting and/or pluton

55 emplacement occur during prograde metamorphism and crustal thickening, and thermal

56 weakening initiates core complex exhumation. In the second scenario, partial melting

57 and/or pluton emplacement are responses to decompression during exhumation and

58 retrograde metamorphism. While melt may aid continued exhumation, it does not have a

59 role in initiating exhumation in this scenario. The Valhalla dome of the Shuswap complex

60 (Fig. 1) serves as an example of the first end member scenario, as leucogranite

61 crystallized during exhumation, immediately following peak metamorphism (Gordon et

62 al., 2008; Spear and Parrish, 1996). The Clearwater complex (Fig. 1) represents the latter

63 scenario, as intrusion of Eocene (c. 52-46 Ma) granites followed Cretaceous-Tertiary

64 prograde metamorphism and exhumation (Burmester et al., 2004; Doughty et al., 2007;

65 Gaschnig et al., 2010; Marvin et al., 1984).

66 Evaluation of the scenarios presented above requires precise constraints on the

67 timing of prograde metamorphism, exhumation, crustal melting, and magmatism.

68 Constraints on the timing of the first three events in the PRC are based on monazite and

69 xenotime petrochronology (Stevens et al., 2015); however, previous geochronological 
70 constraints on granitoids in the PRC lack the precision to determine the timing of

71 emplacement relative to metamorphism and exhumation. This study analyzes zircon from

72 metapelitic rocks and granitoids for U-Pb geochronology, trace element geochemistry,

73 and Lu-Hf isotopes using laser-ablation inductively coupled plasma mass spectrometry

74 (LA-ICPMS), chemical abrasion thermal ionization mass spectrometry (CA-TIMS), and

75 laser-ablation split-stream multi-collector inductively coupled plasma mass spectrometry

76 (LASS-MC-ICPMS). These new data improve the geochronological constraints on the

77 emplacement of granitoids in the PRC footwall and clarify the temporal relationships

78 between crustal melting, magmatism, and exhumation of the PRC, allowing for

79 comparison with other core complexes in the northern belt of the North American

80 Cordillera. These results thus have implications for the significance of crustal melting

81 and magmatism in the formation of metamorphic core complexes.

82

\section{2. Background}

84 The majority of the PRC is located within the northern Idaho panhandle (Fig. 2).

85 The footwall of the PRC was exhumed by the Purcell Trench fault to the east and the

86 Newport fault to the northwest (Fig. 2). The footwall contains the Hauser Lake gneiss,

87 which is a migmatitic, mylonitic, pelitic schist and gneiss that is considered the

88 metamorphosed equivalent of the Prichard Formation, the lowermost unit of the

89 Mesoproterozoic Belt Supergroup (Cressman, 1989; Doughty and Chamberlain, 2008;

90 Lewis et al., 2010; Sears et al., 1998). The Hauser Lake gneiss was intruded by

91 Cretaceous and Eocene granitoids (Fig. 2), as was the low-grade Belt Supergroup in the

92 PRC hanging walls. 
94 Hauser Lake gneiss were reported by Stevens et al. (2015). Monazite and xenotime Th-

$95 \mathrm{~Pb}$ dating indicates metamorphism spanned c. 74-54 Ma, with peak metamorphism at $c$.

96 68-64 Ma. Mineral chemistry and isochemical phase diagrams (pseudosections) indicate

97 that the peak metamorphic assemblage (garnet + sillimanite + biotite \pm muscovite +

98 plagioclase + K-feldspar \pm rutile \pm ilmenite + quartz) records peak $P-T$ conditions of

$99 \sim 9.6-10.3 \mathrm{kbar}$ and $\sim 790^{\circ} \mathrm{C}$. Near isothermal decompression of the PRC began c. $60-57$

100 Ma and melt crystallization occurred c. 54-44 Ma at mid-crustal levels.

101 Thermochronological (K-Ar, $\left.{ }^{40} \mathrm{Ar} /{ }^{39} \mathrm{Ar}\right)$ data are consistent with this interval for the

102 exhumation of the PRC footwall, given cooling through muscovite and biotite closure

103 temperatures $\left(\sim 350^{\circ} \mathrm{C}\right)$ at c. 50-43 Ma (Doughty and Price, 1999; Miller and Engels, 104 1975).

105 Cretaceous igneous intrusions in the PRC footwall include the Selkirk igneous

106 complex (Kaniksu batholith) and the Spokane granite (Fig. 2). The Selkirk igneous

107 complex records U-Pb zircon TIMS multi-grain fraction lower intercept dates of $93.8 \pm$

$108 \quad 0.9 \mathrm{Ma}$ and $93.4 \pm 0.9 \mathrm{Ma}$, although there are U-Pb zircon LA-ICPMS dates as old as $c$.

$109120 \mathrm{Ma}$ (Archibald et al., 1984; Gaschnig et al., 2012). The Spokane granite records U-

$110 \mathrm{~Pb}$ zircon multi-grain fraction lower intercept dates of $92 \pm 5$ Ma for a muscovite-bearing

111 phase and $72 \pm 5$ Ma for a biotite-bearing phase (Bickford et al., 1985).

112 Eocene granitoids that intruded the Hauser Lake gneiss include the Silver Point

113 quartz monzonite, the Wrencoe granodiorite, and the Rathdrum granite (Fig. 2). U-Pb

114 zircon multi-grain fraction lower intercept dates for the Wrencoe and Silver Point

115 plutons, which have been interpreted as a continuous intrusive body (Doughty and Price, 
116 1999), are $52.1 \pm 1.2 \mathrm{Ma}$ and $50.1 \pm 6.3 \mathrm{Ma}$, respectively (Whitehouse et al., 1992). The

117 Rathdrum granite records a zircon U-Pb lower intercept of $52 \pm 10 \mathrm{Ma}$ (Bickford et al.,

118 1985). The Silver Point pluton is mylonitized along the trace of the Newport fault

119 (Doughty and Price, 1999; Harms and Price, 1992). The Rathdrum granite is also

120 mylonitized; both plutons are interpreted as late synextensional (Doughty and Price,

121 1999; Rhodes and Hyndman, 1984).

122 The Hauser Lake gneiss is migmatitic, with visual estimates of $25-40 \%$ in situ

123 (crystallized in place) and/or in-source (migrated from formation site, crystallized in

124 source layer) leucosome in outcrops (Sawyer, 2008; Stevens et al., 2015). Textures

125 observed at thin section to outcrop scale are consistent with patch metatexite migmatite

126 and stromatic metatexite migmatite (Stevens et al., 2015). Leucocratic lenses and layers

127 are primarily concordant with the foliated Hauser Lake gneiss; discordant leucocratic

128 dikes occur more rarely (Stevens et al., 2015).

129 Archean crystalline basement is exposed within the core of an antiform near the

130 center of the PRC (Fig. 2; Doughty et al., 1998). The Pend Oreille gneiss, interpreted to

131 be an orthogneiss, has a zircon U-Pb multi-grain fraction upper intercept date of 2651

$132+21 /-19$ Ma (Doughty et al., 1998). The Pend Oreille gneiss is mantled by the Gold Cup

133 Mountain quartzite, which is overlain by the Hauser Lake gneiss (Doughty et al., 1998).

134 The Gold Cup Mountain quartzite has been correlated with the Neihart quartzite, which

135 underlies the Prichard Formation (Doughty et al., 1998). The Laclede augen gneiss has a

136 zircon U-Pb multi-grain fraction upper intercept date of $1576 \pm 13 \mathrm{Ma}$, and is tectonically

137 interleaved with the Hauser Lake gneiss (Evans and Fischer, 1986; Doughty et al., 1998).

138 Recently recognized exposures of Neoarchean amphibolite, Paleoproterozoic orthogneiss, 
139 and the unconformably overlying Razorback quartzite at the southern end of the PRC

140 (Fig. 2) are correlated with the Pend Oreille gneiss and Gold Cup Mountain quartzite

141 (Buddington et al., 2014; Vervoort et al., 2016; Wang et al., 2014). Zircon Hf isotope

142 compositions suggest that the Neoarchean amphibolite was derived from a mantle source,

143 whereas the Paleoproterozoic basement formed from a mixture of evolved continental

144 crust and depleted mantle (Wang, 2015). The Sm-Nd and Pb isotope compositions and U-

$145 \mathrm{~Pb}$ zircon upper intercept dates suggest a Neoarchean or Paleoproterozoic cratonic lower

146 crustal source for the Silver Point and Wrencoe plutons (Whitehouse et al., 1992). The

147 PRC basement may be continuous with either the Hearne province or the Medicine Hat

148 block to the east, or may represent an independent block of Archean-Proterozoic crust,

149 but is unlikely to be related to the Wyoming craton, which lacks the 1.86 Ga signature of

150 orthogneisses in the Priest River complex (Doughty et al., 1998; Foster et al., 2006;

151 Vervoort et al., 2016; Wang et al., 2015; Whitehouse et al., 1992).

152

153 3. Methods

154

155 3.1 Sample Selection

156 Nine samples from the PRC footwall were analyzed (Fig. 2; Table 1), including

157 six igneous samples and three samples of Hauser Lake gneiss. Samples from the Spokane

158 granite, Silver Point quartz monzonite, Wrencoe granodiorite, and Rathdrum granite were

159 dated because existing geochronological data lack the precision to address this study's

160 goals. The sampled Spokane granite contains muscovite and biotite, and is weakly

161 foliated. The Silver Point and Wrencoe granitoids are biotite-bearing with K-feldspar 
162 phenocrysts; the Silver Point quartz monzonite is locally mylonitized. The sample of

163 Rathdrum granite is from the small Spirit Lake pluton (fine-grained, biotite-bearing, and

164 nonfoliated granite correlated with the Rathdrum granite). An undeformed, biotite-

165 bearing leucocratic dike that crosscuts the Hauser Lake gneiss is included in order to

166 constrain the timing of deformation. Hauser Lake gneiss samples were selected to further

167 constrain the partial melting history. These samples contain the peak metamorphic

168 assemblage garnet + sillimanite + biotite + plagioclase + K-feldspar \pm rutile \pm ilmenite +

169 quartz (Stevens et al., 2015). Samples show evidence of prograde kyanite pseudomorphed

170 by sillimanite, and of retrograde muscovite (Stevens et al., 2015).

171

$172 \quad 3.2$ Methods Overview

173 A detailed description of the methods used in this study is provided in the

174 supplement. Samples were crushed, milled, sieved to $<500 \mu \mathrm{m}$, and washed. Zircon and

175 monazite were separated using standard magnetic and heavy liquid techniques. Most

176 samples were processed using methylene iodide (MeI), whereas Silver Point and

177 Wrencoe pluton samples were processed using lithium polytungstate (LST), with

178 sufficient yield. Zircon grains were hand-picked with a preference for clear, euhedral

179 grains in various colors and sizes from the igneous samples; grains from metapelitic

180 samples were euhedral or subrounded. Both zircon and monazite were separated from the

181 leucocratic dike sample; monazite grains were pale yellow to pink, and varied from

182 small, transparent, inclusion-free, lentil-shaped grains, to larger fractured grains with

183 inclusions. 
185 beakers at Boise State University. Grains and zircon standards were mounted in epoxy

186 and polished until grain centers were exposed. Monazite grains were also mounted in

187 epoxy at Boise State University. Zircon and monazite in these mounts were imaged at the

188 University of Montana using cathodoluminescence (CL) imaging for zircon and

189 backscattered electron (BSE) imaging for monazite via a Tescan Vega 3 scanning

190 electron microscope. Images were used to characterize zircon and monazite zoning and

191 guide placement of in situ analyses (Figs 3, S1-S3).

192 The Hf isotope composition and concurrent $\mathrm{U}-\mathrm{Pb}$ date of zircon were determined

193 via in situ laser ablation split-stream multi-collector inductively coupled plasma mass

194 spectrometry (LASS-MC-ICPMS) at the Radiogenic Isotope and Geochronology

195 Laboratory (RIGL) at Washington State University (Tables S1, S2). The LASS technique

196 is used here to detect inherited Precambrian domains when targeting young (i.e., Eocene)

197 growth domains by monitoring the degree of U-Pb concordance (Fisher et al., 2014a, b).

198 In the case of samples of the Hauser Lake gneiss or inherited cores in younger granites,

199 the U-Pb date and $\mathrm{Hf}$ isotope composition are not reported for analyses that are more than

$200 \quad 10 \%$ discordant. The ${ }^{207} \mathrm{~Pb}$-corrected ${ }^{206} \mathrm{~Pb} /{ }^{238} \mathrm{U}$ dates, determined using Isoplot 3.0

201 (Ludwig, 2003), are reported for analyses of younger zircons (Table S2).

202 LASS analysis was followed by in situ laser ablation inductively coupled plasma

203 mass spectrometry (LA-ICPMS) analysis for zircon U-Pb geochronology and trace

204 elements to further characterize zircon chemistry at Boise State University (Table S3).

205 An attempt was made to analyze zircon grains using both the LASS-MC-ICPMS and LA-

206 ICPMS methods, given interest in the grains and available space for analysis; otherwise, 
207 the two methods were used to characterize as many grains as possible. Finally, selected

208 grains were plucked from epoxy mounts for chemical abrasion thermal ionization mass

209 spectrometry (CA-TIMS, zircon) or isotope dilution thermal ionization mass

210 spectrometry (ID-TIMS, monazite) for U-Pb geochronology at Boise State University

211 (Table S4). CA-TIMS analysis was used to determine high precision dates and interpret

212 igneous crystallization ages. Weighted mean dates were calculated from equivalent dates

213 using Isoplot 3.0 (Ludwig, 2003). Errors for weighted mean dates and dates from

214 individual grains are given at 2 sigma.

215 Samples from the Silver Point and Wrencoe plutons were not analyzed via LA-

216 ICPMS in favor of more precise CA-TIMS analysis. The Spokane, Silver Point, and

217 Wrencoe granitoids and the leucocratic dike were selected for CA-TIMS analysis based

218 on LASS-MC-ICPMS and LA-ICPMS ages and lack of zircon inheritance. Where

219 analysis of whole zircon grains with distinct cores, interpreted as detrital or xenocrystic,

220 was undesirable, zircon tips were broken off and analyzed (Fig. 3, Table S4).

\section{4. Results}

223 The results are summarized by sample, including descriptions of zircon and

224 monazite textures, ranges of U-Pb dates yielded from zircon cores and rims from LASS-

225 ICPMS and LA-ICPMS analysis, and U-Pb dates from CA-TIMS (zircon) and ID-TIMS

226 (monazite) analysis. Dates presented are determined from ${ }^{206} \mathrm{~Pb} /{ }^{238} \mathrm{U}(<1.0 \mathrm{Ga})$ or

$227{ }^{207} \mathrm{~Pb} /{ }^{206} \mathrm{~Pb}(>1.0 \mathrm{Ga})$ ratios. Epsilon $\mathrm{Hf}$ values for the zircons from most granitoids are

228 calculated using the igneous crystallization age (or maximum crystallization age)

229 interpreted from CA-TIMS or LA-ICPMS U-Pb zircon dates rather than the LASS 
230 determinations as the former gives the best determination of the Hf formation age of the

231 magmatic zircon. In the case of inherited zircon cores (e.g., the Hauser Lake gneiss and

232 the Rathdrum granite), $\varepsilon_{\mathrm{Hf}(\mathrm{i})}$ were calculated using corresponding LASS-MC-ICPMS

233 dates, which provide the best determination of the age of the inherited components. For

234 this reason, interpretations regarding granitoid crystallization ages are included in this

235 section and then summarized in the discussion.

236

237 4.1. Hauser Lake Gneiss

238

239 4.1.2. $P R-11-033 B$

240 Zircon has distinct, dark detrital cores and CL bright rims with complex

241 oscillatory zoning representing igneous growth (Fig. S1a). Zircon yield was low; only six

242 small $(65-140 \mu \mathrm{m})$ grains were mounted. Small grain size and the presence of detrital

243 cores prevented Hf isotope analysis. Analysis of four zircon cores yielded dates of $1781 \pm$

24441 to $1277 \pm 61 \mathrm{Ma}(n=4)$ (Fig. 4a; Table S3).

245

246 4.1.3. $P R-10-055$

247 Zircon has distinct cores and rims with oscillatory zoning, interpreted as detrital

248 cores and igneous rims (Fig. S1b). Analysis of zircon cores from 14 grains yielded

249 Proterozoic (2371 \pm 22 to $1563 \pm 26 \mathrm{Ma}, n=12)$ and Cretaceous-Paleocene (66 \pm 1 to

$25060.7 \pm 3.2, n=4$ ) dates (Figs 4a, 5a, 6a; Tables S1, S3). Dates from rims of eight zircon

251 grains vary similarly with values of $2489 \pm 45$ to $1454 \pm 34 \mathrm{Ma}(n=5)$ and $71 \pm 1$ to 61.3 
$252 \pm 1.9 \mathrm{Ma}(n=5)$ (Figs 4a, 5a, 6a; Tables S1, S3). Initial epsilon Hf values vary from -

25316.3 calculated at $66 \mathrm{Ma}$ to +10.1 at $1839 \mathrm{Ma}(n=11)($ Fig. 6b, Table S1).

254

255 4.1.4. $P R-11-040$

256 Zircon has distinct, detrital cores and rims with simple or complex oscillatory,

257 igneous growth zoning (Fig. S1c). Zircon analyses from both cores and rims of fifteen

258 grains yielded Proterozoic dates of $1800 \pm 27$ to $1473 \pm 26 \mathrm{Ma}(n=15)$, and a single

259 Cretaceous date of $97.0 \pm 4.7$ Ma from the rim of a separate grain (Figs 4a, 5a, 6a; Tables

260 S1, S3). Epsilon Hf values vary from -0.7 calculated at $1800 \mathrm{Ma}$ to +7.7 at $1508 \mathrm{Ma}$ (Fig.

261 6b; Table S1).

262

263 4.2. Granitoids

264

265

4.2.1. Spokane Granite (PR-11-038)

266 Zircon has distinct cores with patchy or oscillatory zoning and oscillatory-zoned

267 rims, suggesting igneous growth on xenocrystic cores (Figs 3a, S2a). Tips of grains

268 yielded CA-TIMS dates of $85.57 \pm 0.07$ to $76.49 \pm 0.06 \mathrm{Ma}(n=7)$ (Fig. 7a; Table S4);

269 another grain contains a considerably older component $(165.67 \pm 0.15 \mathrm{Ma})$. Agreement

270 between the youngest LA-ICPMS and CA-TIMS dates suggests a maximum

271 crystallization age of 76.5 Ma. Values for $\varepsilon_{\mathrm{Hf}(77 \mathrm{Ma})}$ range from -21.2 to -13.0 (Fig. 6;

272 Table S2).

273

274 4.2.2. Silver Point Quartz Monzonite (PR-11-010) 
276 cores. The youngest four CA-TIMS dates from whole single grains have a weighted mean 277 of $50.13 \pm 0.02 \mathrm{Ma}$ (MSWD 2.4; probability of fit $=0.06$ ) (Fig. 7b, Table S4), which is 278 interpreted as the igneous crystallization age. One other date is slightly older at $50.52 \pm$ $2790.04 \mathrm{Ma}$ and two others have highly discordant dates that indicate the presence of 280 inherited components. Epsilon Hf values calculated at 50 Ma range from -25.3 to -21.5 $281 \quad($ mean $=-23.7 ; 2 \mathrm{SD}=2.1 ; n=22)($ Fig. 6; Table S2).

\subsubsection{Wrencoe Granodiorite (PR-11-011)}

\subsubsection{Rathdrum Granite (PR-10-043, $P R-11-005)$}

Most zircons have distinct (xenocrystic) cores with oscillatory-zoned mantles on 294 some grains, and thin, CL bright exterior rims (Fig. S3a,b). Analysis of zircon cores in 295 nineteen grains yielded Archean-Proterozoic U-Pb dates of $2672 \pm 34$ to $1519 \pm 38 \mathrm{Ma}(n$ $296=26)$ and Cretaceous-Eocene dates of $79 \pm 2$ to $46.4 \pm 2.0 \mathrm{Ma}(n=9)$ (Figs 4b, 5c, 6a;

297 Tables S1, S3). Analysis of zircon rims from seven grains yielded similar results between 
$2982649 \pm 45$ and $45 \pm 1$ Ma $(n=9)$. The two youngest LA-ICPMS dates are equivalent,

299 with a weighted mean date of $46.4 \pm 1.8 \mathrm{Ma}(\mathrm{MSWD}=0.001$, probability of fit $=0.97)$

300 interpreted as a maximum igneous crystallization age (Fig. 5c). Epsilon Hf values range

301 from -30.0 calculated at 79 Ma to +2.1 at $2632 \mathrm{Ma}$, while one core analysis gives an $\varepsilon_{\mathrm{Hff}}$

302 value of +2.4 at 1519 Ma (Fig. 6b; Table S1).

303

304 4.2.5. Leucocratic Dike (PR-11-014)

305 Zircon has distinct, complexly zoned (xenocrystic) cores and oscillatory-zoned

306 rims that are CL bright (interior rim) and dark (exterior rim) (Figs 3d, S3c). Analyses of

307 zircon cores from five grains yielded $\mathrm{U}-\mathrm{Pb}$ dates of $72.8 \pm 4.1$ to $66.1 \pm 1.4 \mathrm{Ma}(n=5)$

308 (Tables S2, S3). Zircon rims from twenty-five grains yielded U-Pb dates of $78.5 \pm 1.8$ to

$30940.7 \pm 1.2 \mathrm{Ma}$ (Tables S2, S3). The twelve oldest LA-ICPMS dates, which are mostly

310 from CL bright interior rims, yielded a weighted mean date of $69.4 \pm 1.5 \mathrm{Ma}$ (MSWD =

311 1.2; probability of fit $=0.29)($ Fig. $5 \mathrm{~d})$. The youngest four dates, all from CL dark

312 exterior rims, yielded a weighted mean date of 51.8 $\pm 1.5 \mathrm{Ma}(\mathrm{MSWD}=2.0$; probability

313 of fit $=0.12)($ Fig. $5 d)$. While all zircon has low Th/U $(0.00-0.05)$, older zircon has low

314 total REE contents (500-2800 ppm) compared with younger zircon (2600-7400 ppm)

315 (Table S3). CA-TIMS dates from zircon tips are $65.94 \pm 0.06$ to $49.92 \pm 0.04 \mathrm{Ma}(n=8)$

316 (Fig. 7d; Table S4), and likely represent mixtures of the range of dates in the interior and

317 exterior rims, as captured by LA-ICPMS analysis. Monazite grains have either patchy

318 zoning or xenocrystic cores with subtle, oscillatory rims interpreted as igneous in origin

319 (Fig. 3e). Monazite fragments yielded ID-TIMS ${ }^{207} \mathrm{~Pb} /{ }^{235} \mathrm{U}$ dates of $57.56 \pm 0.09$ Ma to

$32049.79 \pm 0.41 \mathrm{Ma}(n=7)$ (Fig. 7d; Table S4). The youngest date is interpreted as the 
321 maximum igneous crystallization age, with all older dates reflecting the presence of

322 inherited components. Values for $\varepsilon_{\mathrm{Hff}(50 \mathrm{Ma})}$ range widely from -16.8 to -2.7 (Fig. 6; Table

323 S2), also indicating incorporation of inherited components in some of these analyses.

\section{5. Discussion}

326 Zircon U-Pb geochronology provides constraints on zircon inheritance and timing

327 of melt crystallization and pluton emplacement. Zircon trace element geochemistry from

328 LA-ICPMS only permits identification of zircon populations from the leucocratic dike.

329 Zircon U-Pb geochronology from CA-TIMS provides the first high-precision date for the

330 Silver Point quartz monzonite, and improves crystallization dates for the Spokane granite,

331 Wrencoe granodiorite, and a leucocratic dike that intrudes the Hauser Lake gneiss. Zircon

332 Hf isotope analysis using LASS-MC-ICPMS allows determination and comparison of

333 magma source characteristics with the PRC basement and Hauser Lake gneiss for the

334 analyzed granitoids. These data create a detailed timeline for the sequence of events in

335 the PRC, clarify the relationship between partial melting, magmatism, and exhumation in

336 the PRC, and permit comparison of the timing of these processes between northern belt

337 core complexes.

339 5.1. Detrital and Metamorphic Zircon Ages

340 Archean-Proterozoic zircon dates from Hauser Lake gneiss samples and the

341 Rathdrum granite are consistent with detrital zircon dates from the Prichard Formation

342 and previously published Archean-Proterozoic zircon dates for the Hauser Lake gneiss

343 (Fig. 4c; Doughty \& Chamberlain, 2008; Lewis et al., 2010; Wang, 2015). This indicates 
344 that the Prichard Formation is the likely protolith of the Hauser Lake gneiss samples in

345 this study, and suggests zircon in the Rathdrum granite is inherited from the Hauser Lake 346 gneiss or the Prichard Formation.

347 Cretaceous-Tertiary zircon and monazite dates from the Hauser Lake gneiss (c.

348 66-61 Ma), Rathdrum granite (c. 67-46 Ma), and leucocratic dike (c. 78-41 Ma) are

349 synchronous with ${ }^{208} \mathrm{~Pb} /{ }^{232} \mathrm{Th}$ monazite dates recording prograde to peak (c. 68-64 Ma)

350 metamorphism, isothermal decompression and retrograde metamorphism, and melt

351 crystallization (c. 54-44 Ma) in the Hauser Lake gneiss (Stevens et al., 2015).

352

353 5.2. Crystallization Ages

354 Zircon CA-TIMS and LA-ICPMS dates constrain the age of igneous

355 crystallization of granitoids within the PRC footwall. The Silver Point quartz monzonite

356 is the only sample with a precise interpreted crystallization age because it is the only unit

357 without a significant inherited zircon component or a prolonged crystallization history.

358 Scattered dates from the other samples give maximum crystallization ages based on the

359 youngest dates. A summary of interpreted crystallization ages are: $<76.5 \pm 0.1$ Ma for

360 the Spokane granite, $50.13 \pm 0.02$ for the Silver Point quartz monzonite, c. 47.9 for the

361 Wrencoe pluton, $<46.4 \pm 1.8$ Ma for the Rathdrum granite, and $<49.8 \pm 0.4$ for the

362 leucocratic dike.

364 5.3. Magmatic Sources

365 Analyses of detrital zircon from the Hauser Lake gneiss and inherited cores from

366 the Rathdrum granite have both positive and negative $\varepsilon_{\mathrm{Hff}}$ values ranging from - 10 to 
$367+10$. These results are used to constrain the Lu-Hf evolution of the potential source

368 materials to the granitoids in this study (Fig. 6b,c). The Wrencoe and Silver Point plutons

369 have homogeneous $\varepsilon_{\mathrm{Hf}(\mathrm{i})}$ values, each with a range of fewer than four $\varepsilon_{\mathrm{Hf}}$ units, suggesting

370 crystallization from relatively homogeneous magmas and a lack of inherited components

371 (Fig. 6c). The spread of $\varepsilon_{\mathrm{Hf}(\mathrm{i})}$ values for analyses from the Spokane granite and leucocratic

372 dike (Fig. 6c) can be attributed to the incorporation of inherited zircon components in the

373 analyses. The Hf isotope compositions for zircon from the granitoids are consistent with

374 derivation from Archean-Proterozoic sources, possibly the PRC basement and/or the

375 Hauser Lake gneiss, which they intrude (Fig. 6b).

376 Modeling the Lu-Hf isotope evolution of the PRC basement and detrital zircon of

377 the Hauser Lake gneiss offers constraints on the source materials from which Eocene

378 granitoids may have formed. The $\mathrm{Hf}$ isotope compositions, when calculated at $50 \mathrm{Ma}$

379 would be approximately -22 to -8 for the Hauser Lake gneiss, and -44 to -18 for

380 Neoarchean amphibolite and Paleoproterozoic orthogneisses (Wang, 2015). The Spokane

381 granite has $\varepsilon_{\mathrm{Hf}(77 \mathrm{Ma})}$ values of -21 to -13 , and the leucocratic dike has a mean $\varepsilon_{\mathrm{Hf}(50 \mathrm{Ma})}$ of

382 approximately -10 . These values overlap with those projected from a Hauser Lake gneiss

383 source, but are more radiogenic than the Hf isotope compositions calculated at $50 \mathrm{Ma}$ for

384 Archean or Paleoproterozoic basement lithologies. Conversely, the Silver Point and

385 Wrencoe plutons and the Rathdrum granite have $\varepsilon_{\mathrm{Hf}(\mathrm{i})}$ values that more closely overlap

386 the Lu-Hf isotope evolution of Archean and Paleoproterozoic basement lithologies (Fig.

387 6c). Constraints on the source of the Rathdrum granite are more difficult to obtain from

388 the limited LASS-MC-ICPMS data; however, the Rathdrum granite contains abundant

389 inherited zircon that include c. 2.6 Ga and $1.8 \mathrm{Ga}$ components, consistent with 1) detrital 
390 populations in the Hauser Lake gneiss, and 2) the ages and $\varepsilon_{\mathrm{Hf}(\mathrm{i})}$ values of basement

391 amphibolites and orthogneisses (Doughty et al., 1998; Doughty and Chamberlain, 2008;

392 Lewis et al., 2010; Vervoort et al., 2016; Wang, 2015). More extensive LA-ICPMS

393 analysis of inherited cores in the Rathdrum granite yield a range of ages not presently

394 observed in the basement orthogneisses, strongly suggesting the Hauser Lake gneiss as its

395 source.

396 The $\varepsilon_{\mathrm{Hf(i)}}$ values for zircons in the Spokane granite and leucocratic dike suggest

397 that partial melting of Hauser Lake gneiss could serve as a viable source. The less

398 radiogenic values for the zircons from the Silver Point and Wrencoe plutons, and possibly

399 the Rathdrum granite, suggest that these plutons may have had greater input from

400 Paleoproterozoic, and perhaps Archean, components (Fig. 6b, c). This distinction

401 suggests that the $c$. 50-48 Ma plutons (Silver Point, Wrencoe) were derived from partial

402 melting of PRC basement sources, whereas Cretaceous-Eocene leucocratic material was

403 sourced from the Hauser Lake gneiss, indicating contributions from an additional magma

404 source either during or following exhumation of the Priest River complex. More deeply

405 sourced late synkinematic to post-kinematic plutons suggest that exhumation permitted

406 formation and/or emplacement of these melts.

407 The zircon Hf isotope data are consistent with previously published data and

408 interpretations that suggest igneous intrusions in the PRC footwall derive, at least in part,

409 from crustal melting of the metamorphosed Belt Supergroup, or its protoliths, and that the

410 more unradiogenic Silver Point and Wrencoe plutons have a Neoarchean or

411 Paleoproterozoic cratonic lower crustal source (Whitehouse et al., 1992). These data

412 support the presence of Archean basement in the PRC, but do not discriminate between 
413 the Hearne province, Medicine Hat block, or an unknown Archean province, due to the

414 lack of constraints on the nature of the basement rocks throughout this region (Foster et

415 al., 2012; Vervoort et al., 2016)

416

417 5.4. Constraints on Exhumation

418 The crystallization ages for the Silver Point and Wrencoe plutons are

419 distinguishable, indicating that these plutons are not continuous, but rather represent

420 discrete pulses of crustal melting during the exhumation of the PRC. These crystallization

421 ages also bracket the timing of deformation and exhumation in the PRC, indicating that

422 extension along the Newport fault, which crosscuts the mylonitized Silver Point pluton,

423 and/or the Purcell Trench fault ceased by c. 47.9 Ma, when the undeformed Wrencoe

424 pluton was emplaced. Crystallization of the cross cutting leucocratic dike at c. 49.8 Ma is

425 consistent with this interpretation. Mica cooling ages from $\mathrm{K}-\mathrm{Ar}$ and ${ }^{40} \mathrm{Ar} /{ }^{39} \mathrm{Ar}$

426 thermochronology indicate that the Hauser Lake gneiss reached mid-crustal levels by $c$.

427 50-43 Ma (Doughty and Price, 1999; Miller and Engels, 1975). These Eocene plutons

428 were emplaced at mid-crustal levels ( 12 km) following near-isothermal decompression

429 to 5.0-4.4 kbar (Stevens et al., 2015).

430

431 5.5. Evolution of the PRC

432 The data presented above, in combination with previously published work, permit

433 construction of the most detailed timeline yet available for metamorphism, crustal

434 anatexis, magmatism, and exhumation in the PRC (Fig. 8). The Spokane granite was

435 emplaced and crystallized during Sevier crustal thickening and prograde metamorphism, 
436 prior to the c. 64 Ma peak metamorphism of the Hauser Lake gneiss (Stevens et al.,

437 2015). The majority of partial melting, 14-24 volume \% melt, was produced during

438 prograde metamorphism (Stevens et al., 2015). By c. 60-57 Ma the exhumation of the

439 PRC footwall had been initiated (Stevens et al., 2015). Initially, exhumation followed a

440 near-isothermal $P-T$ path, decompressing to 5.5-4.0 kbar before cooling and

441 crystallization of melt c. 54 Ma; partial melting of the crust during retrograde

442 metamorphism was limited to a few volume percent (Stevens et al., 2015). The Silver

443 Point pluton was emplaced at mid-crustal levels at c. 50 Ma along the Newport fault.

444 Exhumation continued along the Newport fault, shearing and mylonitizing the Silver

445 Point pluton in the process. The c. 47.9 Ma Wrencoe pluton was emplaced shortly after

446 the cessation of extension along the Newport fault, along with the c. 46 Ma Rathdrum

447 granite. By c. 44-43 Ma, the PRC footwall cooled through mica closure temperatures

$448\left(\sim 300^{\circ} \mathrm{C}\right)$ and remaining crustal melt had crystallized (Miller and Engels, 1975; Stevens

449 et al., 2015).

450 Examining the relationship between the crystallization of igneous units relative to

451 the timing of metamorphism and exhumation of the Hauser Lake gneiss permits

452 evaluation of hypothetical exhumation scenarios. The Selkirk igneous complex

453 crystallized prior to the Cretaceous-Tertiary metamorphism of the Hauser Lake gneiss,

454 whereas crystallization of the Spokane granite occurred during early prograde

455 metamorphism. The Silver Point, Wrencoe, and Rathdrum plutons were emplaced at mid-

456 crustal levels following the majority of near-isothermal decompression of the PRC. This

457 time frame is consistent with a scenario in which magma is formed and/or emplaced as a

458 response to exhumation, rather than triggering exhumation. It is possible, however, that 
459 emplacement of the Silver Point pluton along the Newport fault may have eased

460 displacement during the final phases of extension and exhumation.

461 These data do not fully resolve the role of prograde crustal anatexis in the

462 exhumation of the PRC. The PRC contains the Spokane dome, a gneiss dome that

463 exhibits neither the relatively high melt volume, the extensively interconnected melt

464 network, nor the near-vertical foliation patterns suggestive of diapiric rise, as seen in the

465 Valhalla or Thor-Odin domes (Fig. 2; Gordon et al., 2008; Norlander et al., 2002;

466 Whitney et al., 2004). We interpret the Spokane dome to have formed during c. 60-48

467 Ma exhumation of the PRC. Pseudosection modeling indicates that 14-24 volume \%

468 partial melt was produced during prograde metamorphism in the PRC, prior to the onset

469 of exhumation at c. $60 \mathrm{Ma}$ (Stevens et al., 2015). The melt connectivity transition, when

470 the melt phase is interconnected, is achieved at melt volumes of $\sim 7 \%$, which reduces rock

471 strength by $\sim 90 \%$ (Rosenberg and Handy, 2005). It is thus expected that partial melt

472 weakened the crust within the PRC prior to exhumation; however, crustal weakening

473 associated with the solid-to-liquid transition that occurs at $\sim 40$ volume $\%$ partial melt was

474 not achieved in the PRC (Rosenberg and Handy, 2005). The solid-to-liquid transition is

475 more likely associated with diatexite migmatite, such as that of the Shuswap gneiss

476 domes. It is suggested that the resulting increase in magma buoyancy at this transition

477 may cause the gravitational instability that leads to gneiss dome formation

478 (Vanderhaeghe, 2009). This suggests that partial melting in the PRC was sufficient to

479 weaken the crust and potentially allow for crustal flow, but was not a sufficient melt

480 volume to trigger exhumation. 
483 Available data and interpretations regarding the timing of metamorphism, peak

484 metamorphism, pluton emplacement, onset of exhumation, leucosome crystallization, and

485 cooling for several deeply exhumed northern belt complexes and gneiss domes have been

486 compiled (Table S5 and references therein) and summarized in Figure 9. Data for the

487 Bitterroot complex include timing of metamorphism (c. $64 \mathrm{Ma}, 7-8 \mathrm{kbar}, 700{ }^{\circ} \mathrm{C}$; House

488 et al., 1997; Foster and Fanning, 1997), crystallization ages for early, main, and

489 synextensional plutons, and thermochronological data (Fig. 9, Table S5 and references

490 therein). These data demonstrate that peak metamorphism occurred during the main

491 phase of plutonism, followed by slow cooling. Rapid exhumation (mylonitization, and

492 doming) occurred c. 48 Ma (Foster et al., 2001; Foster and Raza, 2002; House \& Hodges,

493 1994; House et al., 1997), whereas synextensional pluton crystallization ages range from

494 c. 52 Ma to c. 47 Ma (e.g., Foster et al., 2001; Foster et al., 2007; House et al., 2002). The

495 apparent record of a lengthy cooling history for the Bitterroot complex, in comparison to

496 those of other complexes, is an artifact of abundant low-temperature thermochronology

497 data for the Bitterroot complex.

498 Data for the Cretaceous-Tertiary evolution of the Clearwater complex south of

499 the PRC include the timing of latest metamorphism, magmatism, and cooling

500 (thermochronology) (Fig. 9; Table S5). Evidence for Cretaceous-Eocene crustal anatexis

501 in the exhumed units of the Clearwater complex has not been described. Peak

502 metamorphism ( 8-11 kbar, 700 C, c. 64 Ma; Doughty et al., 2007; Grover et al.,

503 1992) was followed by exhumation c. 59 Ma (Doughty et al., 2007). Intrusion of the 
504 Roundtop, Beaver Creek, and Bungalow plutons occurred during exhumation and cooling

505 (Burmester et al., 2004; Gaschnig et al., 2010; Marvin et al., 1984).

506 Data for the Valhalla dome in the Shuswap complex include the timing of

507 metamorphism, crystallization of prograde leucogranite and later equivalents, and

508 cooling. Peak metamorphism (c. $61 \mathrm{Ma}, \sim 8 \mathrm{kbar},>800^{\circ} \mathrm{C}$; Schaubs et al., 2002; Spear \&

509 Parrish, 1996) was immediately followed by the crystallization of leucosome (Fig. 9;

510 Table S5). Several phases of the Ladybird leucogranite record crystallization ages of $c$.

51161 Ma to c. 47 Ma (Parrish et al., 1988; Sevigny \& Parrish, 1993). Exhumation is

512 interpreted to have occurred as late as $c .51 \mathrm{Ma}$, based on zircon rim ages obtained

513 through depth profiling (Gordon et al., 2009). The pattern of crystallization and cooling

514 in the Thor-Odin dome is similar to that of the Valhalla dome (Fig. 9; Table S5). Data

515 from the Thor-Odin dome are limited primarily to the timing of crystallization of

516 leucosome and the Ladybird leucogranite, and cooling based on thermochronological

517 data. Crystallization of the Ladybird leucogranite at c. 60 Ma (Vanderhaeghe et al., 1999)

518 was followed by crystallization of leucosome, exhumation at c. $56 \mathrm{Ma}$, and cooling.

519 In the Bitterroot complex and Valhalla and Thor-Odin domes, crustal anatexis and

520 pluton emplacement immediately preceded exhumation (Fig. 9). Additionally, significant

521 crustal anatexis (diatexite migmatite) is observed within the lower units of the Valhalla

522 and Thor-Odin domes (e.g., Gordon et al., 2008; Vanderhaeghe et al., 1999). This

523 suggests that these complexes are examples of an end member scenario in which partial

524 melting and magmatism occur during prograde metamorphism, resulting in thermal

525 weakening and core complex exhumation. Thermal weakening followed by exhumation

526 is consistent with models developed by researchers working in the Valhalla and Thor- 
527 Odin domes who hypothesize that significant crustal anatexis led to diapirism within the

528 middle crust, initiating low-angle rolling hinge detachment zones along which

529 displacement was enhanced by syntectonic leucogranite laccoliths (Gordon et al., 2008;

530 Norlander et al., 2002; Vanderhaeghe et al., 1999). Foster et al. (2001) suggest that

531 Tertiary extension was focused in the Bitterroot core complex due to the large volume of

532 magma likely present at the time.

533 Exhumation of the PRC was preceded by crustal anatexis (metatexite migmatite),

534 but pluton emplacement at exposed levels followed the onset of exhumation by 10 Ma

535 (Figs 8, 9). Neither crustal anatexis nor plutonism preceded the exhumation of the

536 Clearwater complex; pluton emplacement followed the onset of exhumation by $\sim 7 \mathrm{Ma}$

537 (Fig. 9; Table S5). This indicates that the PRC and Clearwater are examples of the second

538 hypothetical scenario, in which pluton emplacement is primarily a response to

539 decompression. Although exhumation in the PRC may have been influenced by partial

540 melting, triggers other than partial melting must have been involved in the exhumation of

541 the Clearwater complex.

542

5435.7 Modeling Core Complex Exhumation

544 The varied relationships between crustal anatexis, pluton emplacement, and

545 exhumation among the northern belt complexes indicate that exhumation triggers vary

546 significantly. Individualized models for core complex development need not take these

547 variations into account; however, attempts to develop generalized models, including

548 numerical models, for the initiation and evolution of metamorphic core complexes must

549 account for them. The two-dimensional numerical models of Tirel et al. (2008), Rey et al. 
550 (2009a, b), and Bendick and Baldwin (2009) detail extension and exhumation of

551 thickened continental crust during the development of core complexes, and are applicable

552 to the development of core complexes in the northern North American Cordillera.

553 Although the models vary in configuration, boundary conditions, and model output data,

554 each produces a geologically plausible scenario for northern belt core complexes, while

555 allowing for variation in model parameters (e.g., thermal conditions, extension rate, melt

556 fraction).

557 An important comparison of these models is how each allows for the assessment

558 of the hypothetical end member scenarios regarding melting and magmatism as either

559 causes or consequences of core complex exhumation. The model of Tirel et al. (2008)

560 imposes a pre-existing density-viscosity anomaly, such as a granitic pluton, to localize a

561 detachment fault. Rey et al. (2009b) impose a crustal detachment to localize strain,

562 although the authors address the possibility of a point anomaly, such as an intrusion. The

563 Rey et al. (2009b) model incorporates partial melting, but model experiments suggest that

564 partial melting is secondary to strain rate in determination of the form of the resultant

565 complex. The Bendick and Baldwin (2009) model imposes a decrease in effective

566 viscosity, preferring either crustal anatexis or pluton emplacement as the cause.

$567 \quad$ For all three numerical models described above, melting and/or magmatism

568 (granitic intrusion, crustal detachment or intrusion, or decreased effective viscosity)

569 figure in the initiation of exhumation of metamorphic core complexes. Furthermore, all

570 three models permit, but do not require, near-isothermal decompression, allowing for

571 decompression melting and pluton emplacement during retrograde metamorphism. Thus,

572 all three models potentially apply to the exhumation of core complexes in the northern 
573 Cordillera, with the possible exception of the Clearwater complex. Given the apparent

574 absence of pre- or early synextensional magmatism in both the Priest River and

575 Clearwater complexes, and the lack of Cretaceous-Eocene partial melting in the

576 Clearwater complex, the Bendick and Baldwin (2009) model is preferred for its ability to

577 address the variability in northern Cordilleran metamorphic core complexes.

578

579 6. Conclusions

$580 \quad$ Analysis of zircon from the Hauser Lake gneiss and the granitoids that intrude it

581 provides constraints on the temporal relationships between metamorphism, crustal

582 anatexis, magmatism, and exhumation in the PRC. The Spokane granite completed

583 crystallization by $76.5 \mathrm{Ma}$, likely prior to or during early prograde metamorphism of the

584 Hauser Lake gneiss. Distinct crystallization ages for the Silver Point and Wrencoe

585 plutons indicate multiple pulses of crustal melting during exhumation, and constrain

586 exhumation and deformation in the PRC footwall to no later than c. 50-48 Ma. The Silver

587 Point and Wrencoe plutons were likely derived from PRC basement lithologies, with

588 significant input from Paleoproterozoic orthogneisses, whereas partial melting of the

589 Hauser Lake gneiss served as a likely source for the Spokane granite and leucocratic

590 dike. Late pluton emplacement at exposed levels relative to the initiation of exhumation

591 at c. 60 Ma suggests magmatism in the PRC is a response to, rather than a trigger of,

592 exhumation.

593 The timing of magmatism relative to exhumation is variable for deeply exhumed

594 core complexes in the northern North American Cordillera, indicating that the influence

595 of partial melting and magmatism is variable among core complexes. Numerical models 
596 for the exhumation of metamorphic core complexes are consistent with this observation,

597 suggesting that melting and magmatism are influential in exhumation, but allowing for

598 variability between core complexes.

599

600 ACKNOWLEDGEMENTS

601 This research was supported by NSF EAR-1019669, granted to J. A. Baldwin and R.

602 Bendick, and a GSA Graduate Student Research Grant to L. M. Stevens. The authors

603 gratefully acknowledge C. Knaack for technical assistance, and R. Bendick, R. Lewis,

604 and M. Schmitz for conversations that improved this work. The authors thank D. Foster

605 and two anonymous reviewers for their constructive reviews of this manuscript.

606

607 FIGURES

608

609

610

Fig. 1. Metamorphic core complexes of the northern North American Cordillera. (a) The

611

612

613

614

615

616

617

618

619

620

621

622

623

624

625

626

627

628

629 northern, central, and southern belts of complexes in the North American Cordillera. (b) Core complexes in the northern belt of the North American Cordillera, including gneiss domes and complexes within the Shuswap complex. FC - Frenchman Cap; GF - Grand Forks; K- Kettle; O - Okanagan; SRP - Snake River Plain; T-O - Thor-Odin; V Valhalla. (Modified from Stevens et al., 2015, and references therein)

Fig. 2. Simplified geologic map of the footwall of the Priest River complex. Sample locations for this study are shown. Cross section lines A-A' and B-B' are referenced in Fig. 9. (Modified from Lewis et al., 2012; Stevens et al., 2015; Wang, 2015)

Fig. 3. Zircon cathodoluminescence and monazite backscattered electron images for grains analyzed by CA-TIMS or ID-TIMS. Zircon analyzed by CA-TIMS for (a) Spokane granite, (b) Silver Point pluton, (c) Wrencoe pluton, and (d) the leucocratic dike cross cutting the HLG. (e) Monazite analyzed by ID-TIMS for the leucocratic dike within the HLG. Dashed lines show approximate boundary of zircon tips broken off for analysis; otherwise, whole zircon grains were analyzed. Monazite grains were broken into two fragments that were analyzed separately. The ${ }^{206} \mathrm{~Pb} /{ }^{238} \mathrm{U}$ dates are given. Circles represent locations of LASS-MC-ICPMS analyses (Figs S2, S3).

630

Fig. 4. Archean-Proterozoic LA-ICPMS dates. (a) Concordia diagram for the Hauser Lake gneiss. (b) Concordia diagram for the Rathdrum granite. Error ellipses are $2 \sigma$ and 
631 are shaded by sample. (c) Histogram comparing metamorphic and detrital zircon

$632{ }^{207} \mathrm{~Pb} /{ }^{206} \mathrm{~Pb}$ LA-ICPMS dates from the Hauser Lake gneiss and Prichard Formation. Dates

633 from the Prichard formation, the interpreted protolith of the Hauser Lake gneiss, are from

634 quartzites (Lewis et al., 2010). Dates from the Hauser Lake gneiss from previous studies

635 are from quartzites and gneisses (Doughty and Chamberlain, 2008; Lewis et al., 2010).

636

637 Fig. 5. Ranked ${ }^{206} \mathrm{~Pb} /{ }^{238} \mathrm{U}$ date plots for Cretaceous-Tertiary LA-ICPMS zircon analyses.

638 (a) Hauser Lake gneiss. (b) Spokane granite. (c) Rathdrum granite. (d) Leucocratic dike.

639 Box heights are $2 \sigma$.

640

641 Fig. 6. Plots of $\varepsilon_{\mathrm{Hf}(\mathrm{i})}$ Vs. age for zircon analyses and a Concordia diagram for Archean-

642 Proterozoic LASS-MC-ICPMS analyses. (a) Concordia diagram for Archean-Proterozoic

643 LASS-MC-ICPMS analyses from the Hauser Lake gneiss and Rathdrum granite. (b) Plot

644 of $\varepsilon_{\mathrm{Hf}(\mathrm{i})}$ Vs. age for all analyses from this study. Plot shows the evolution of Archean-

645 Proterozoic basement (dark field) and Hauser Lake gneiss (light field), with crustal Lu/Hf

$646=0.015$ (Goodge and Vervoort, 2006). (c) Detail of plot (a) for $\varepsilon_{\mathrm{Hf}(\mathrm{i})}$ for analyses with

$647{ }^{206} \mathrm{~Pb} /{ }^{238} \mathrm{U}$ dates $<100 \mathrm{Ma}$. Most error bars are smaller than, or approximately the same

648 size as, the symbols representing the data.

649

650

651

652

653

654

655

656

657

658

659

660

661

Fig. 7. Zircon and monazite U-Pb dates TIMS dates. (a) Spokane granite. (b) Silver Point quartz monzonite. (c) Wrencoe granodiorite. (d) Leucocratic dike. Box heights are $2 \sigma$.

662

663

664

665

Fig. 8. Schematic cartoon depicting the evolution of the PRC. See Fig. 2 for the locations of A-A' and B-B'. A timeline (not to scale) shows the timing of metamorphism, magmatism, exhumation, and crystallization relative to the depicted stages. a)

Emplacement of the Spokane granite at c. 76.5 Ma. (b) Peak metamorphism and crustal anatexis at c. 64 Ma. (c) The initiation of exhumation, c. 60 Ma. (d) Exhumation and emplacement of the Silver Point pluton, c. 50 Ma. (e) The final stages of exhumation and the emplacement of the Wrencoe pluton, c. $48 \mathrm{Ma}$. (f) The present day, shown with basement. NF - Newport Fault; PTF - Purcell Trench Fault; R - Rathdrum granite; S Spokane granite; SD - Spokane Dome; SP - Silver Point pluton; W - Wrencoe pluton. Pluton locations depict depth of emplacement and do not imply a magma source.

666

667

668

669

670

671

672

Fig. 9. Comparison of the timing of metamorphism, magmatism, cooling, crystallization, and exhumation for deeply exhumed northern belt core complexes. Data is compiled from sources listed in Table S5.

\section{TABLES}

Table 1. Samples included in this study.

673

674

675

676 
681

682

683

684

685

686

687

688

689

690

691

692

693

694

695

696

697

698

699

700

701

702

703

704

705

706

707

708

709

710

711

712

713

714

715

716

717

718

719

720

721

722

\section{REFERENCES}

Archibald, D.A., Krogh, T.E., Armstrong, R.L., Farrar, E., 1984. Geochronology and tectonic implications of magmatism and metamorphism, southern Kootenay arc and neighboring regions, southeastern British Columbia. II. Mid-Cretaceous to Eocene. Canadian Journal of Earth Sciences 21, 567-583.

Armstrong, R.L., 1982. Cordilleran metamorphic core complexes - from Arizona to southern Canada. Annual Review of Earth and Planetary Sciences 10, 129-154.

Armstrong, R. L., Ward, P., 1991. Evolving geographic patterns of Cenozoic magmatism in the North American Cordillera: The temporal and spatial association of magmatism and metamorphic core complexes. Journal of Geophysical Research 96, 13201-13224.

Bendick, R., Baldwin, J., 2009. Dynamic models for metamorphic core complex formation and scaling: The role of unchannelized collapse of thickened continental crust. Tectonophysics 477, 93-101.

Bickford, M.E., Rhodes, B. P., Hyndman, D.W., 1985. Age of mylonitization in the southern Priest River complex, northern Idaho and northeastern Washington. Geological Society of America, Abstracts with Programs 17, 341.

Bouvier, A., Vervoort, J.D., Patchett, P.J., 2007. The Lu-Hf and Sm-Nd isotopic composition of CHUR: constraints from unequilibrated chondrites and implications for the bulk composition of terrestrial planets. Earth and Planetary Science Letters 219, 311.

Buddington, A.M., Doughty, T., Wang, D., Lewis, R.S., Vervoort, J., Fisher, C.M., 2014. Newly recognized pre-Belt quartzite in the southern Priest River complex. Geological Society of America, Abstracts with Programs 46, 70.

Burmester, R.F., McClelland, W.C., Lewis, R.S., 2004. U-Pb dating of plutons along the transfer zone between the Bitterroot and Priest River metamorphic core complexes. Geological Society of America, Abstracts with Programs 36, 72.

Chase, R.B., Bickford, M.E., Arruda, E.C., 1983. Tectonic implications of Tertiary intrusion and shearing within the Bitterroot dome, northeastern Idaho Batholith. The Journal of Geology 91, 462-470.

Coney, P.J., 1980. Cordilleran metamorphic core complexes: An overview, in: Crittenden, M.D., Coney, P.J., Davis, G.H. (Eds.), Cordilleran metamorphic core complexes. Geological Society of America, Boulder, Colorado, pp. 7-31.

Coney, P.J., Harms, T.A., 1984. Cordilleran metamorphic core complexes: Cenozoic extensional relics of Mesozoic compression. Geology 12, 550-554. 
723

724

725

726

727

728

729

730

731

732

733

734

735

736

737

738

739

740

741

742

743

744

745

746

747

748

749

750

751

752

753

754

755

756

757

758

759

760

761

762

763

764

765

766

767

768
Cressman, E.R., 1989. Reconnaissance stratigraphy of the Prichard Formation (Middle Proterozoic) and the early development of the Belt Basin, Washington, Idaho, and Montana. U.S. Geological Survey Professional Paper 1490.

Davis, G.H. and Coney, P.J. (1979) Geologic development of the Cordilleran metamorphic core complexes. Geology 7, 120-124.

Doughty, P.T., Chamberlain, K.R., 2008. Protolith age and timing of Precambrian magmatic and metamorphic events in the Priest River complex, northern Rockies. Canadian Journal of Earth Sciences 45, 99-116.

Doughty, P.T., Chamberlain, K.R., Foster, D.A., Sha, G.S., 2007. Structural, metamorphic, and geochonologic constraints on the origin of the Clearwater core complex, northern Idaho, in: Sears, J.W., Harms, T.A., Evenchick, C.A. (Eds.), Whence the Mountains? Inquiries into the Evolution of Orogenic Systems: A Volume in Honor of Raymond A. Price. Geological Society of America, Boulder, Colorado, pp. 211-241.

Doughty, P.T., Price, R.A., 1999. Tectonic evolution of the Priest River complex, northern Idaho and Washington: A reappraisal of the Newport fault with new insights on metamorphic core complex formation. Tectonics 18, 375-393.

Doughty, P.T., Price, R.A., Parrish, R.R., 1998. Geology and U-Pb geochronology of Archean basement and Proterozoic cover in the Priest River complex, northwestern United States, and their implications for Cordilleran structure and Precambrian continent reconstructions. Canadian Journal of Earth Sciences 35, 39-54.

Evans, K. V., Fischer, L. B., 1986. U-Pb geochronology of two augen gneiss terranes, Idaho - new data and tectonic implications. Canadian Journal of Earth Sciences 23, 1919-1927.

Fisher, C.M., Vervoort, J.D., DuFrane, S.A., 2014a. Accurate Hf isotope determinations of complex zircons using the "laser ablation split stream" method. Geochemistry, Geophysics, Geosystems $\left(\mathrm{G}^{3}\right)$ 15, 121-139.

Fisher, C.M., Vervoort, J.D., Hanchar, J.M., 2014b. Guidelines for reporting zircon Hf isotopic data by LA-MC-ICPMS and potential pitfalls in the interpretation of these data. Chemical Geology 363, 125-133.

Foster, D.A., Fanning, C.M., 1997. Geochronology of the northern Idaho batholith and the Bitterroot metamorphic core complex: Magmatism preceding and contemporaneous with extension. Geological Society of America Bulletin 109, 379-394.

Foster, D.A., Mueller, P.A., Mogk, D.W., Wooden, J.L., Vogl, J.J., 2006. Proterozoic 
786

787

788

789

790

791

792

793

794

795

796

797

798

799

800

801

802

803

804

805

806

807

808

809

810

811

812 evolution of the western margin of the Wyoming craton: implications for the tectonic and magmatic evolution of the northern Rocky Mountains. Canadian Journal of Earth Sciences 43, 1601-1619.

Foster, D.A., Schafer, C., Fanning, C.M., Hyndman, D.W., 2001. Relationships between crustal partial melting, plutonism, orogeny, and exhumation: Idaho-Bitterroot batholith. Tectonophysics 342, 313-350.

Foster, D.A., Mueller, P. A., Heatherington, A., Gifford, J. N., Kalakay, T. J., 2012. LuHf systematics of magmatic zircons reveal a Proterozoic crustal boundary under the Cretaceous Pioneer batholith, Montana. Lithos 142-143, 216-225.

Gans, P.B., Mahood, G.A., Schermer, E., 1989. Synextensional magmatism in the Basin and Range province: A case study from the eastern Great Basin. Geological Society of America Special Paper 233.

Gaschnig, R., Vervoort, J., Lewis, R. S., 2012. The Kaniksu and Idaho batholiths, northern U.S. Cordillera: Close relatives or a case of mistaken identity? Geological Society of America, Abstracts with Programs 44, 383.

Gaschnig, R.M., Vervoort, J.D., Lewis, R.S., McClelland, W.C., 2010. Migrating magmatism in the northern US Cordillera: in situ U-Pb geochronology of the Idaho batholith. Contributions to Mineralogy and Petrology 159, 863-883.

Goodge, J.W., Vervoort, J.D., 2006. Origin of Mesoproterozoic A-type granites in Laurentia: Hf isotope evidence. Earth and Planetary Science Letters 243, 711-731.

Gordon, S.M., Grove, M., Whitney, D.L., Schmitt, A.K., Teyssier, C., 2009. Timetemperature-fluid evolution of migmatite dome crystallization: Coupled U-Pb age, $\mathrm{Ti}$ thermometry, and $\mathrm{O}$ isotopic ion microprobe depth profiling of zircon and monazite. Chemical Geology 262, 186-201.

Gordon, S.M., Whitney, D.L., Teyssier, C., Grove, M., Dunlap, W.J., 2008. Timescales of migmatization, melt crystallization, and cooling in a Cordilleran gneiss dome: Valhalla complex, southeastern British Columbia. Tectonics 27, TC4010.

Grover, T.W., Rice, J.M., Carey, J.W., 1992. Petrology of aluminous schist in the Boehls Butte region of northern Idaho - phase equilibria and P-T evolution. American Journal of Science 292, 474-507.

Harms, T.A., Price, R.A., 1992. The Newport fault: Eocene listric normal faulting, mylonitization, and crustal extension in northeast Washington and northwest Idaho. Geological Society of America Bulletin 104, 745-761. 
813

814

815

816

817

818

819

820

821

822

823

824

825

826

827

828

829

830

831

832

833

834

835

836

837

838

839

840

841

842

843

844

845

846

847

848

849

850

851

852

853

854

855

856

857

858
House, M.A., Bowring, S.A., Hodges, K.V., 2002. Implications of middle Eocene epizonal plutonism for the unroofing history of the Bitterroot metamorphic core complex, Idaho-Montana. Geological Society of America Bulletin 114, 448-461.

House, M.A., Hodges, K.V., 1994. Limits on the tectonic significance of rapid cooling events in extensional settings - insights from the Bitterroot metamorphic core complex, Idaho-Montana. Geology 22, 1007-1010.

House, M.A., Hodges, K.V., Bowring, S.A., 1997. Petrological and geochronological constraints on regional metamorphism along the northern border of the Bitterroot batholith. Journal of Metamorphic Geology 15, 753-764.

Lang, H.M., Rice, J.M., 1985. Geothermometry, geobarometry and T-X(Fe-Mg) relations in metapelites, Snow Peak, northern Idaho. Journal of Petrology 26, 889-924.

Lewis, R.S., Link, P.K., Stanford, L.R., Long, S.P., 2012. Geologic map of Idaho. Idaho Geological Survey, 1:750,000.

Lewis, R.S., Vervoort, J.D., Burmester, R.F., Oswald, P.J., 2010. Detrital zircon analysis of Mesoproterozoic and Neoproterozoic metasedimentary rocks of north-central Idaho: implications for development of the Belt-Purcell basin. Canadian Journal of Earth Sciences 47, 1383-1404

Lister, G.S., Baldwin, S.L., 1993. Plutonism and the origin of metamorphic core complexes. Geology 21, 607-610.

Ludwig, K.R., 2003. User’s Manual for Isoplot 3.00. Berkeley Geochronology Center: Berkeley, California.

Marvin, R.F., Zartman, R.E., Obradovich, J.D., Harrison, J.E., 1984. Geochronometric and lead isotope data on samples from the Wallace $1^{\circ} \times 2^{\circ}$ quadrangle, Montana and Idaho: U.S. Geological Survey Miscellaneous Field Studies Map MF-1354-G, $1: 250,000$.

Miller, F.K., Engels, J.C., 1975. Distribution and trends of discordant ages of plutonic rocks of northeastern Washington and northern Idaho. Geological Society of America Bulletin 86, 517-528.

Norlander, B.H., Whitney, D.L., Teyssier, C., Vanderhaeghe, O., 2002. Partial melting and decompression of the Thor-Odin dome, Shuswap metamorphic core complex, Canadian Cordillera. Lithos 61, 103-125.

Parrish, R.R., Carr, S.D., Parkinson, D.L., 1988. Eocene extensional tectonics and geochronology of the southern Omineca Belt, British Columbia and Washington. Tectonics 7, 181-212. 
Rey, P.F., Teyssier, C., Whitney, D.L., 2009. Extension rates, crustal melting, and core complex dynamics. Geology 37, 391-394.

Rey, P.F., Teyssier, C., Whitney, D.L., 2009b. The role of partial melting and extensional strain rates in the development of metamorphic core complexes. Tectonophysics 477, 135-144.

Rhodes, B.P., Hyndman, D.W., 1984. Kinematics of mylonites in the Priest River “metamorphic core complex," northern Idaho and northeastern Washington. Canadian Journal of Earth Science 21, 1161-1170.

Rosenberg, C.L., Handy, M.R., 2005. Experimental deformation of partially melted granite revisited: implications for the continental crust. Journal of Metamorphic Geology 23, 19-28.

Sawyer, E.W., 2008. Atlas of Migmatites. The Canadian Mineralogist Special Publication 9, NRC Research Press, Ottawa.

Schaubs, P.M., Carr, S.D., Berman, R.G., 2002. Structural and metamorphic constraints on ca. 70 Ma deformation of the northern Valhalla complex, British Columbia: implications for the tectonic evolution of the southern Omineca belt. Journal of Structural Geology 24, 1195-1214.

Sears, J.W., Chamberlain, K.R., Buckley, S.N., 1998. Structural and U-Pb geochronological evidence for $1.47 \mathrm{Ga}$ rifting in the Belt basin, western Montana. Canadian Journal of Earth Sciences 35, 467-475.

Sevigny, J.H., Parrish, R.R., 1993. Age and origin of Late Jurassic and Paleocene granitoids, Nelson Batholith, southern British Columbia. Canadian Journal of Earth Sciences 30, 2305-2314.

Söderlund, U., Patchett, P.J., Vervoort, J.D., Isachsen, C.E., 2004. The ${ }^{176}$ Lu decay constant determined by Lu-Hf and U-Pb isotope systematics of Precambrian mafic intrusions. Earth and Planetary Science Letters 219, 311-324.

Spear, F.S., Parrish, R.R., 1996. Petrology and cooling rates of the Valhalla complex, British Columbia, Canada. Journal of Petrology 37, 733-765.

Stevens, L.M., Baldwin, J.A., Cottle, J.M., Kylander-Clark, A.R.C., 2015. Phase equilibria modelling and LASS monazite petrochronology: P-T-t constraints on the evolution of the Priest River core complex, northern Idaho. Journal of Metamorphic Geology 33, 385-411.

Tirel, C., Brun, J.P., Burov, E., 2008. Dynamics and structural development of metamorphic core complexes. Journal of Geophysical Research-Solid Earth 113, B04403. 
905

906

907

908

909

910

911

912

913

914

915

916

917

918

919

920

921

922

923

924

925

926

927

928

929

930

931

932

933

934

935

936

937

938

939
Vanderhaeghe, O., 1999. Pervasive melt migration from migmatites to leucogranite in the Shuswap metamorphic core complex, Canada: control of regional deformation. Tectonophysics 312, 35-55.

Vanderhaeghe, O., 2009. Migmatites, granites and orogeny: Flow modes of partiallymolten rocks and magmas associated with melt/solid segregation in orogenic belts. Tectonophysics 477, 119-134.

Vanderhaeghe, O., Teyssier, C., 2001. Crustal-scale rheological transitions during lateorogenic collapse. Tectonophysics 335, 211-228.

Vervoort, J. D., Lewis, R. S., Fisher, C., Gaschnig, R. M., Jansen, A. C., Brewer, R., 2016. Neoarchean and Paleoproterozoic crystalline basement rocks of northcentral Idaho: Constraints on the formation of western Laurentia. GSA Bulletin 128, 94-109.

Wang, D., 2015. Age and origin of the Archean and Paleoproterozoic basement rocks from the Priest River and Clearwater complexes, northern Idaho. Washington State University, Pullman.

Wang, D., Vervoort, J., Fisher, C., Lewis, R.S., Buddington, A.M., Doughty, P.T., 2014. The basement terranes of north central Idaho: filling in the gap between the Priest River and Clearwater complexes. Geological Society of America, Abstracts with Programs 46, 33.

Whitehouse, M.J., Stacey, J.S., Miller, F.K., 1992. Age and nature of the basement in northeastern Washington and northern Idaho: Isotopic evidence from Mesozoic and Cenozoic granitoids. Journal of Geology 100, 691-701.

Whitney, D.L., Teyssier, C., Rey, P., Buck, W.R., 2013. Continental and oceanic core complexes. Geological Society of America Bulletin 125, 273-298.

Whitney, D.L., Teyssier, C., Vanderhaeghe, O., 2004. Gneiss domes and crustal flow. Geological Society of America Special Papers 380, 1-19. 


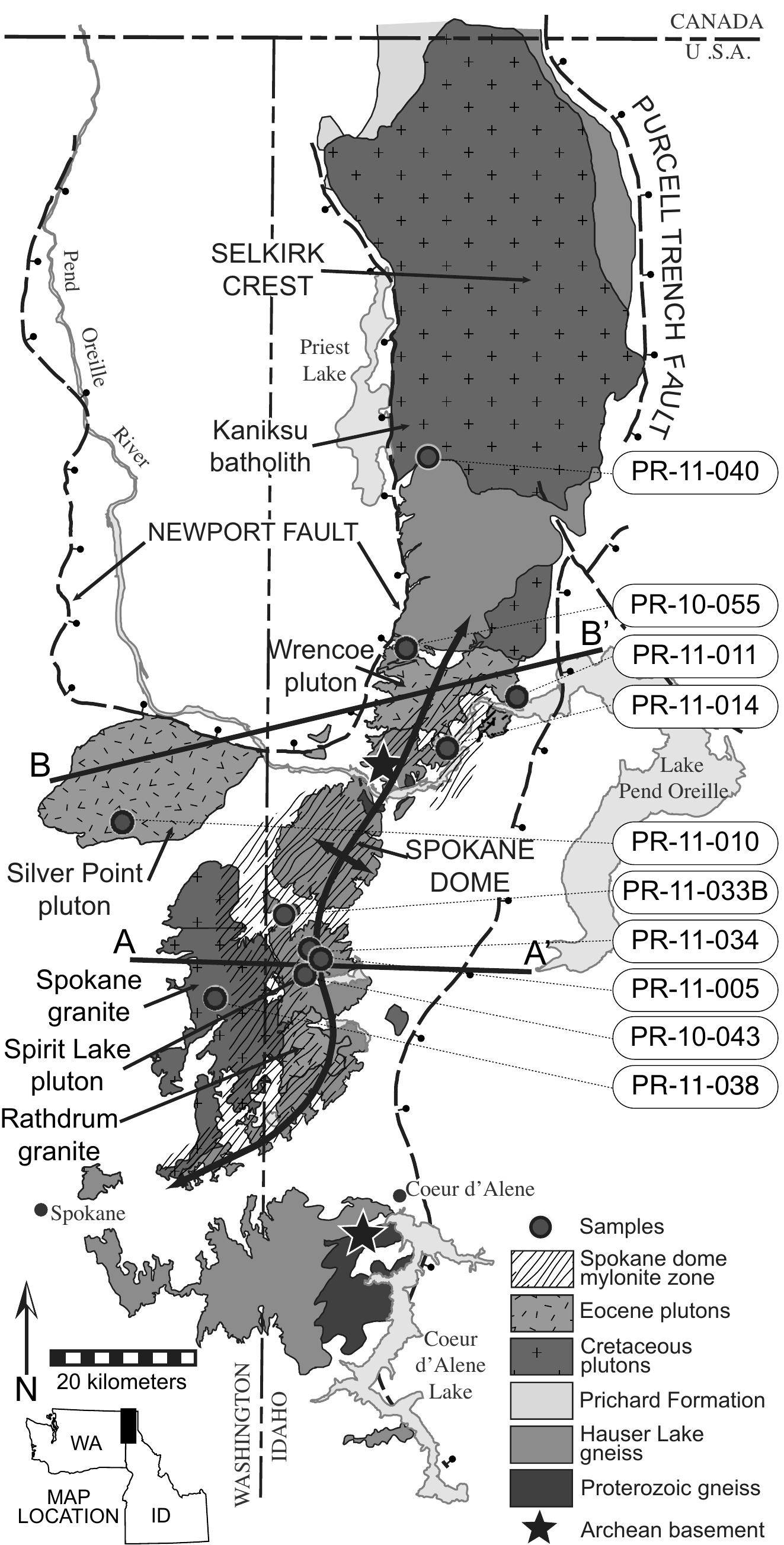




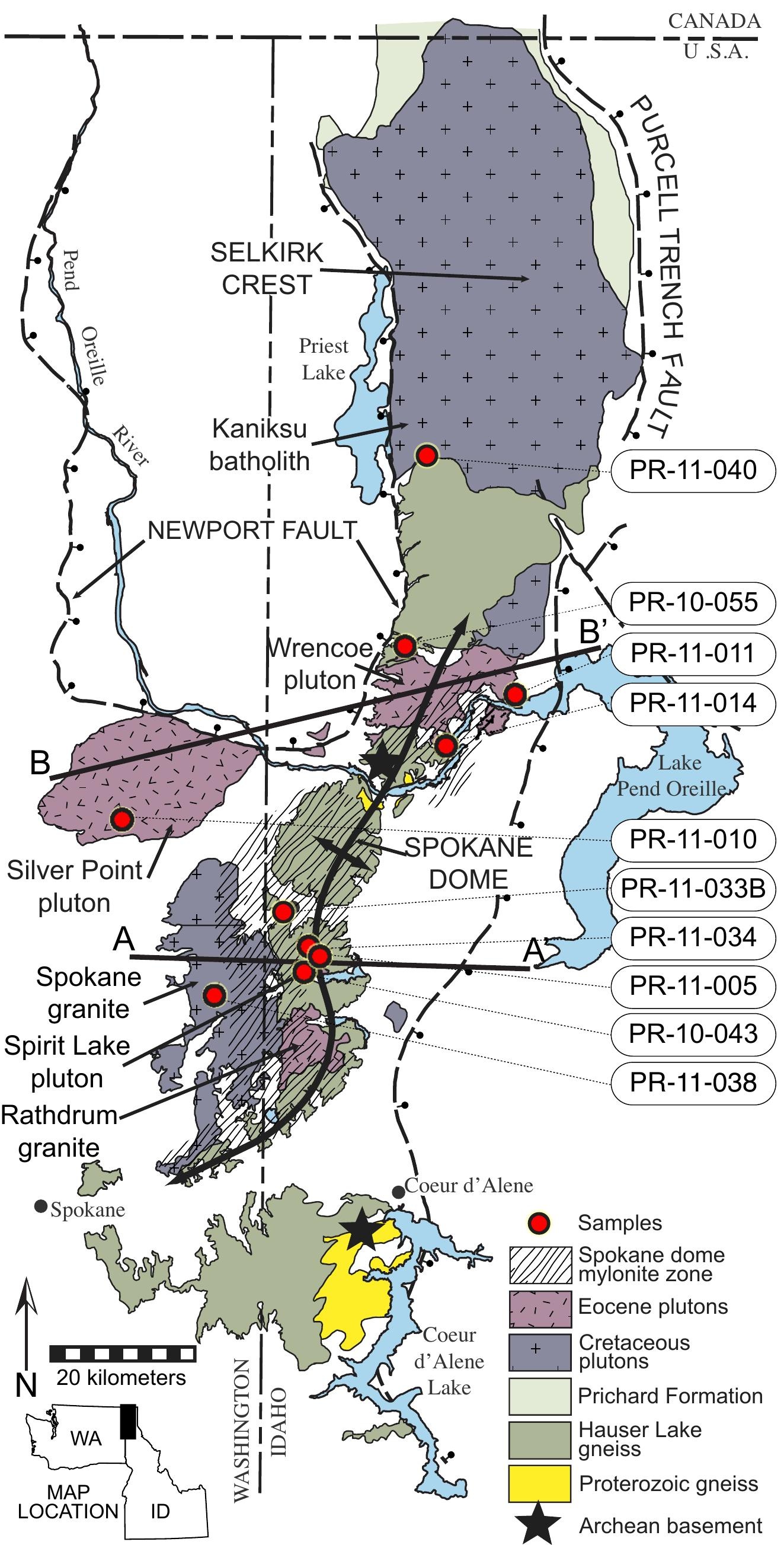


(a) Spokane granite (PR-11-038)

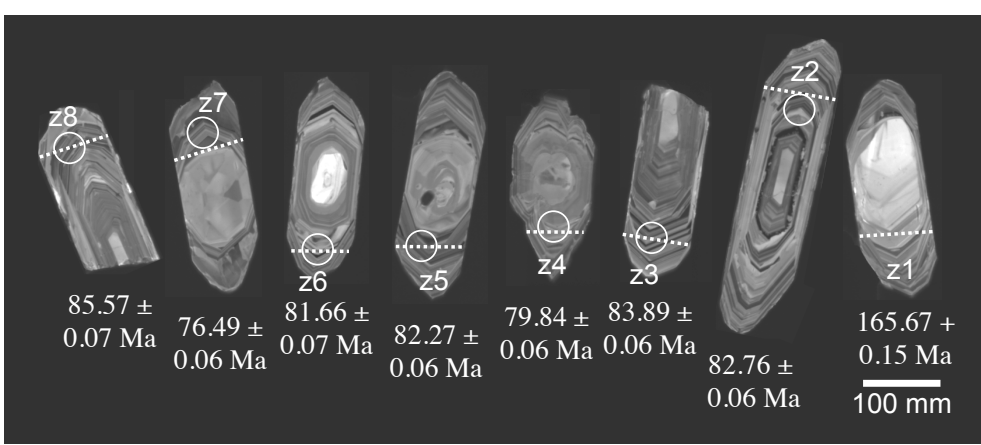

(b) Silver Point quartz monzonite (PR-11-010)

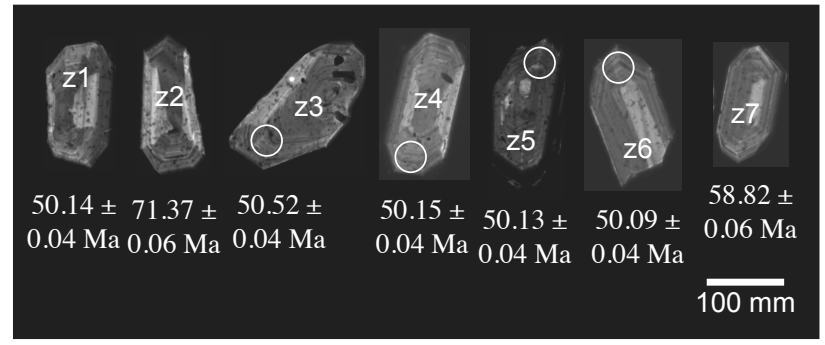

(c) Wrencoe granodiorite (PR-11-011)

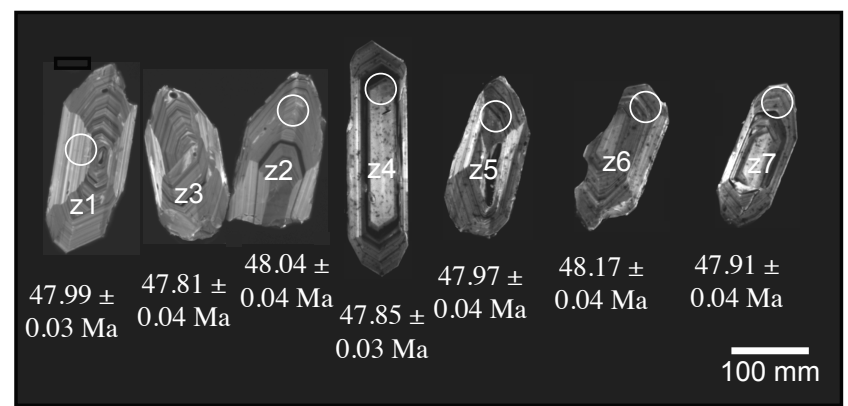

(d) Leucocratic dike (PR-11-014, zircon)

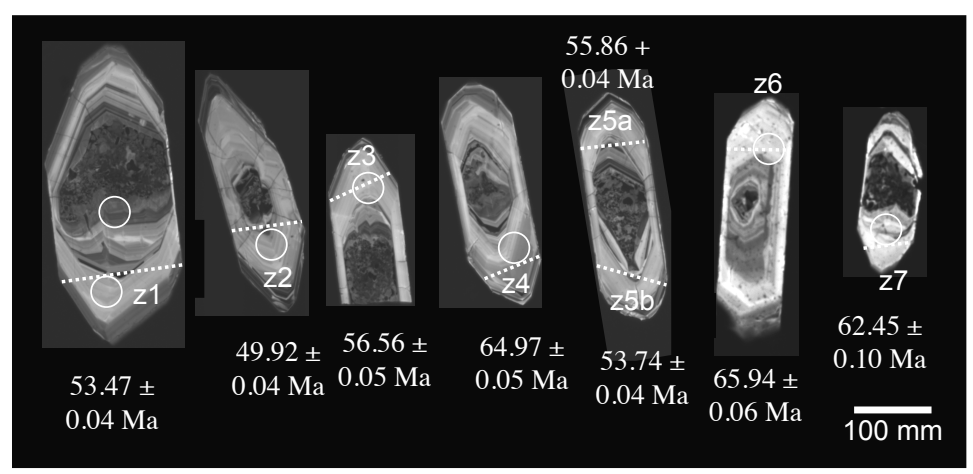

(e) Leucocratic dike (PR-11-014, monazite)

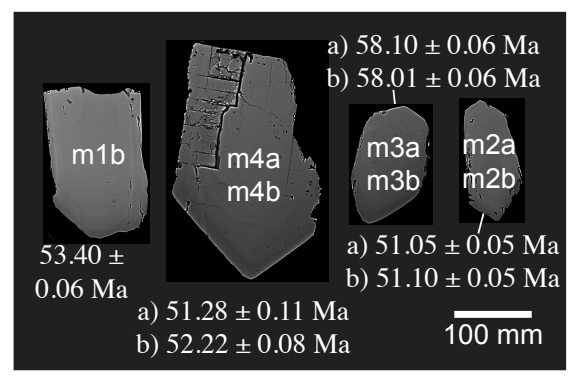


(a) Spokane granite (PR-11-038)

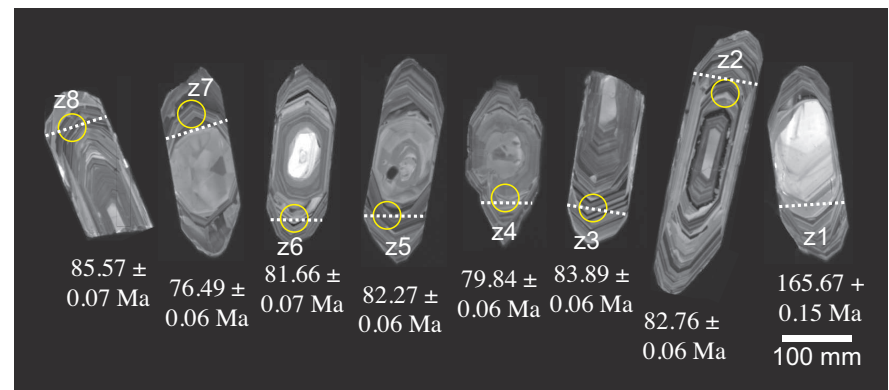

(b) Silver Point quartz monzonite (PR-11-010)

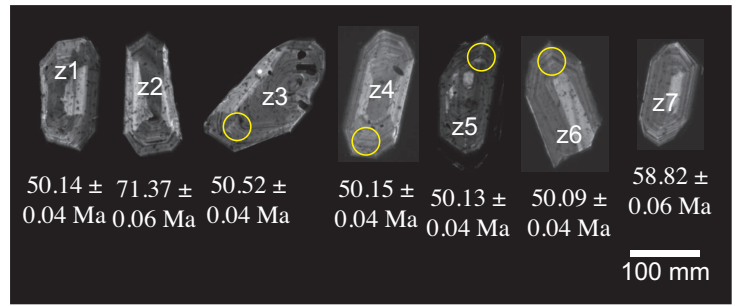

(c) Wrencoe granodiorite (PR-11-011)

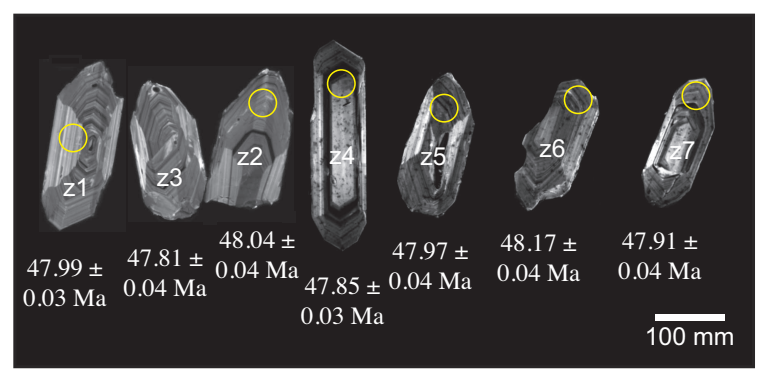

(d) Leucocratic dike (PR-11-014, zircon)

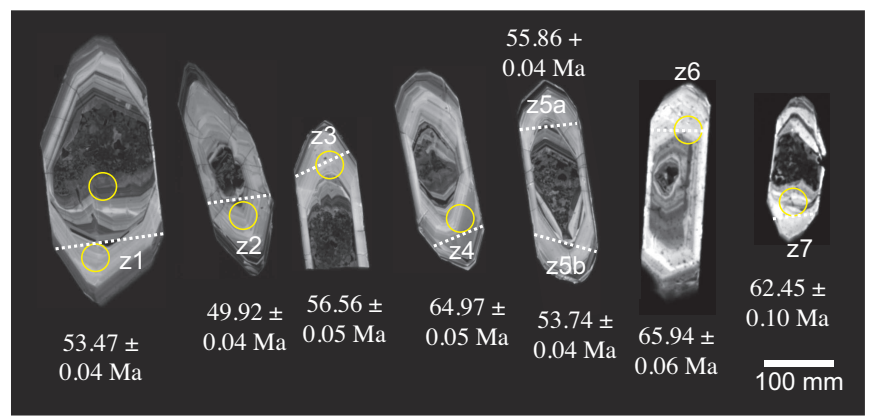

(e) Leucocratic dike (PR-11-014, monazite)

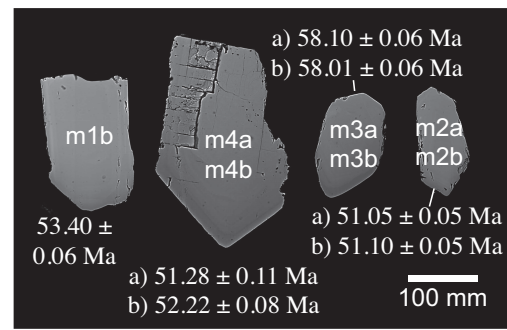


Figure 4.

(a) Hauser Lake gneiss, Archean-Proterozoic dates

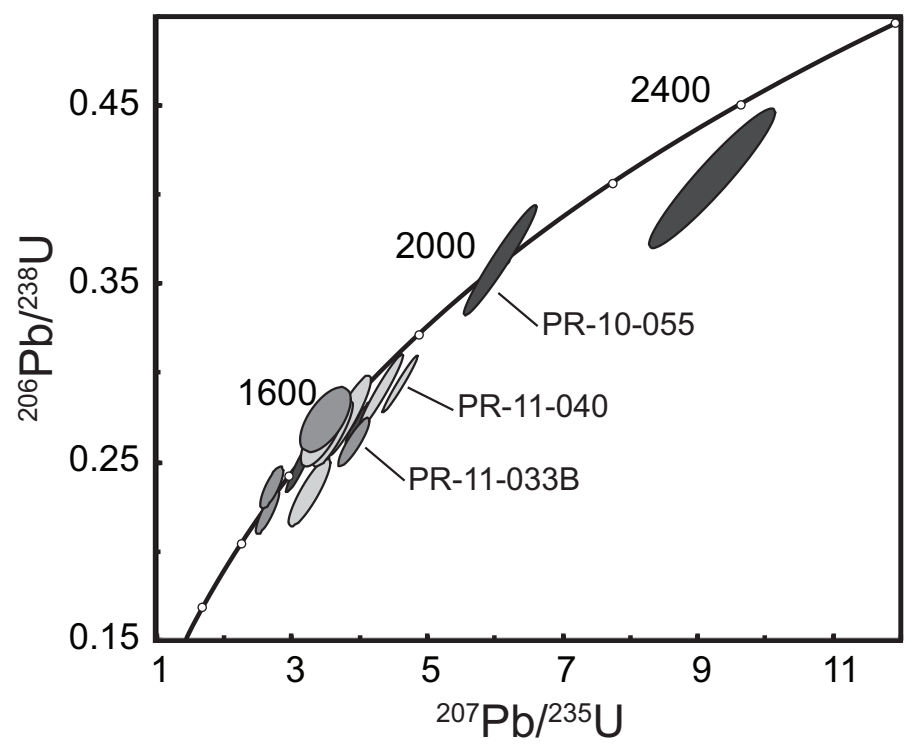

(b) Rathdrum granite, Archean-Proterozoic dates

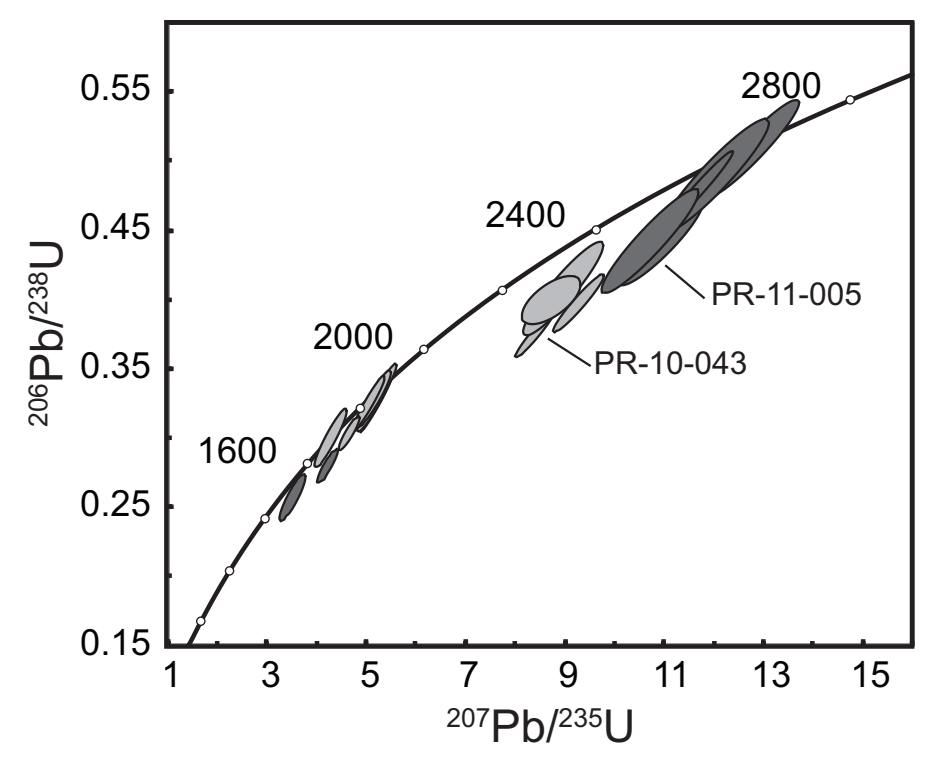

(c) Histogram for detrital dates from the Prichard Formation and Hauser Lake gneiss

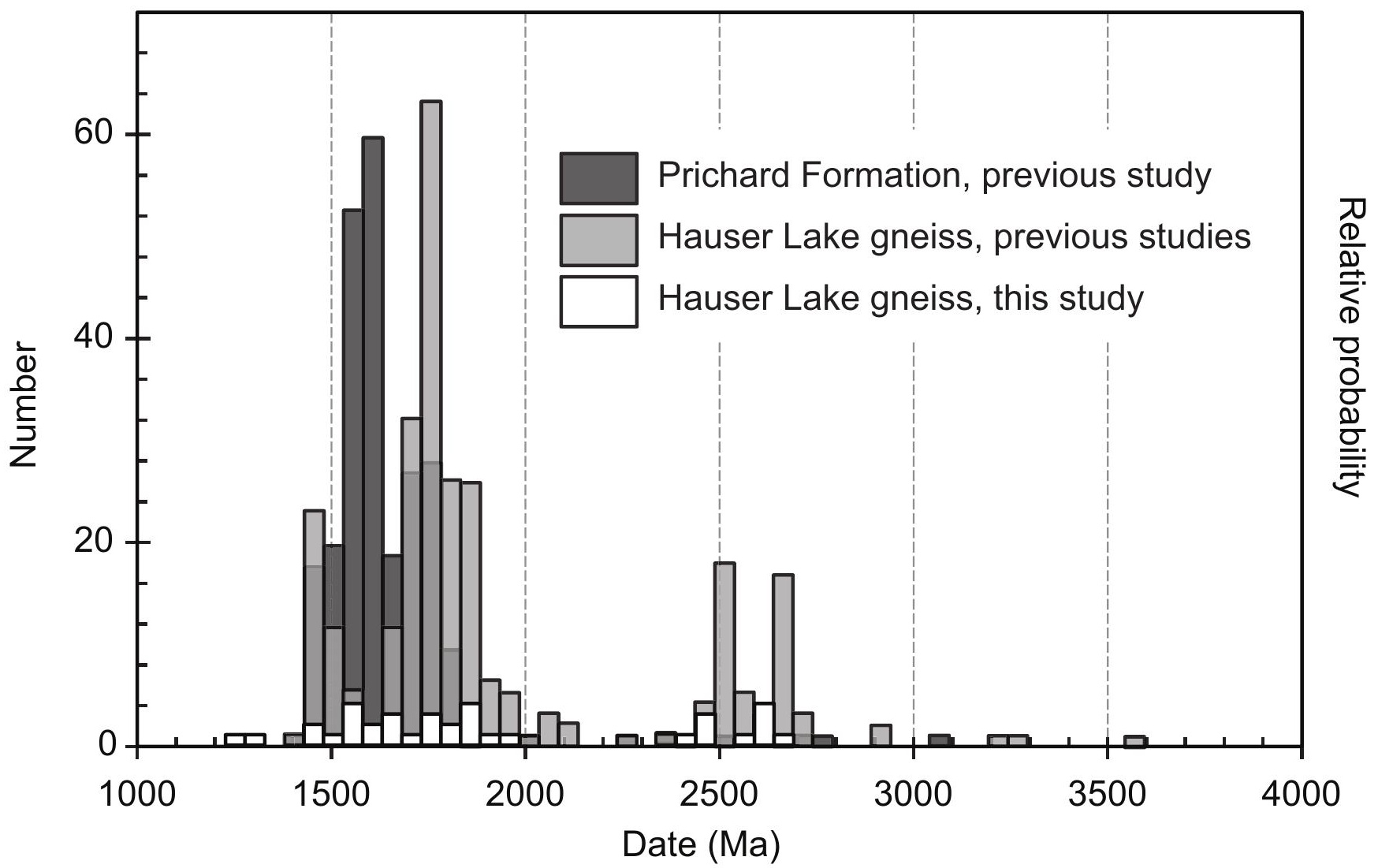


(a) Hauser Lake gneiss, Archean-Proterozoic dates

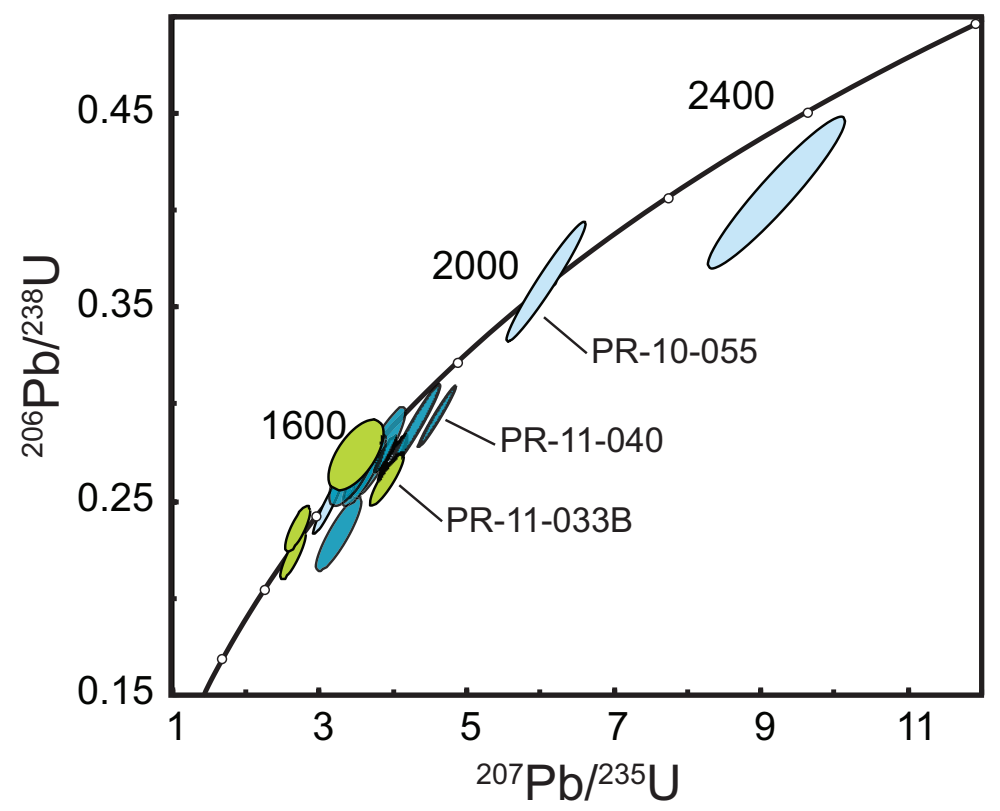

(b) Rathdrum granite, Archean-Proterozoic dates

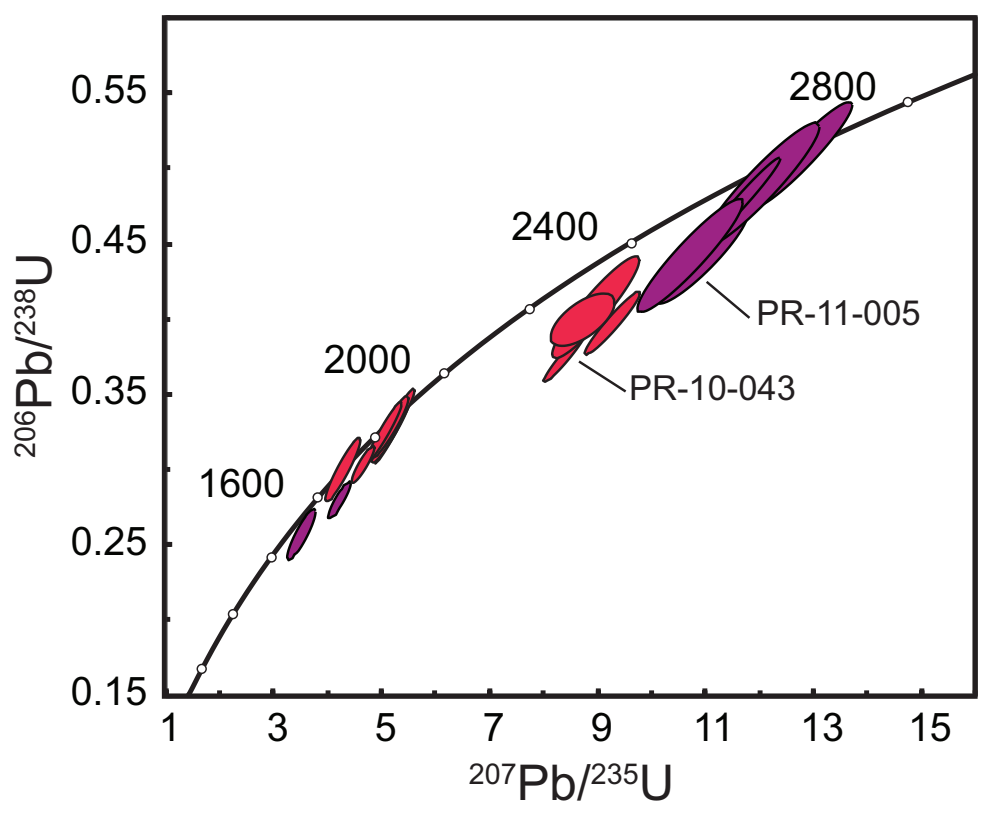

(c) Histogram for detrital dates from the Prichard Formation and Hauser Lake gneiss

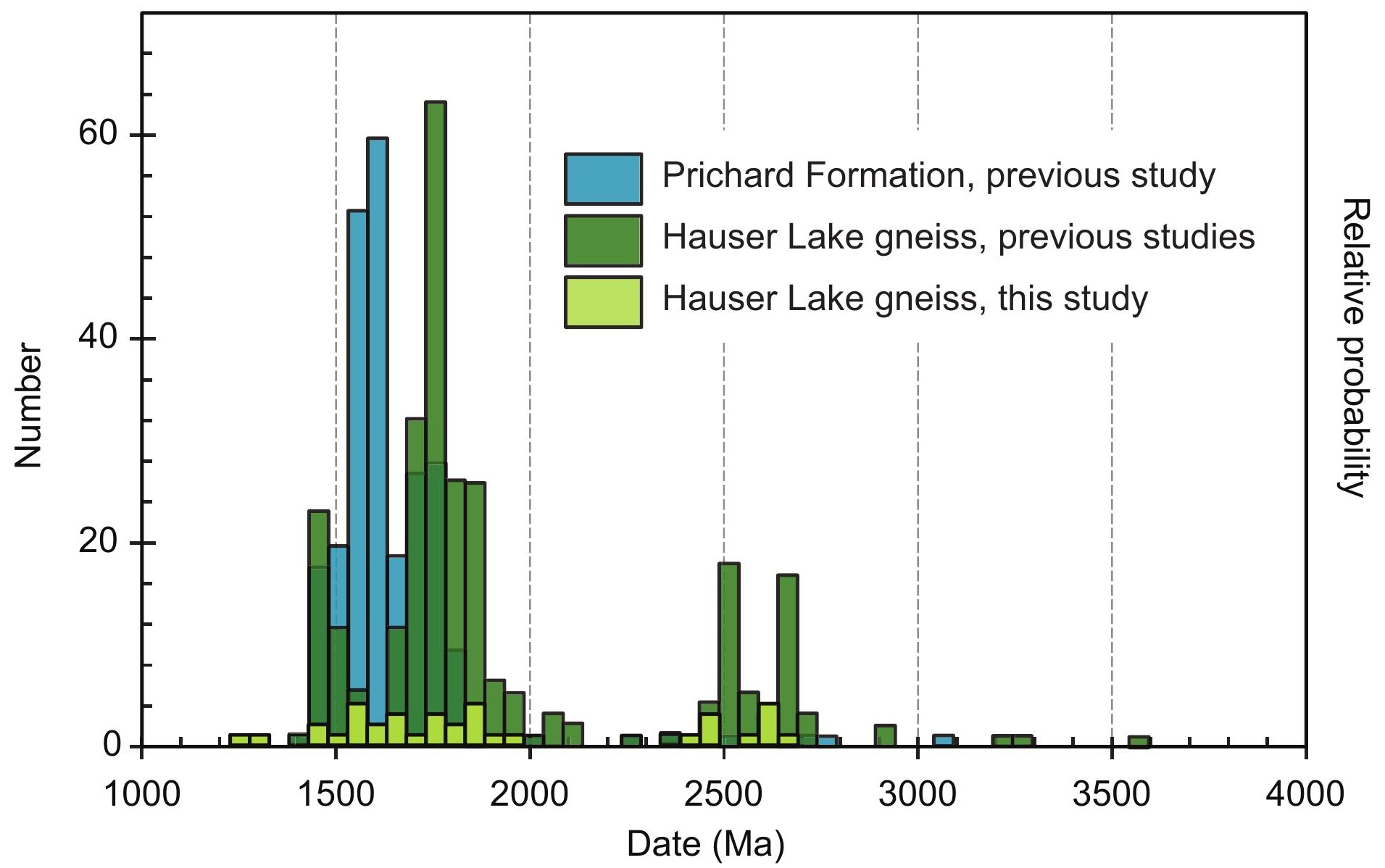


Figure 5

(a) Hauser Lake gneiss

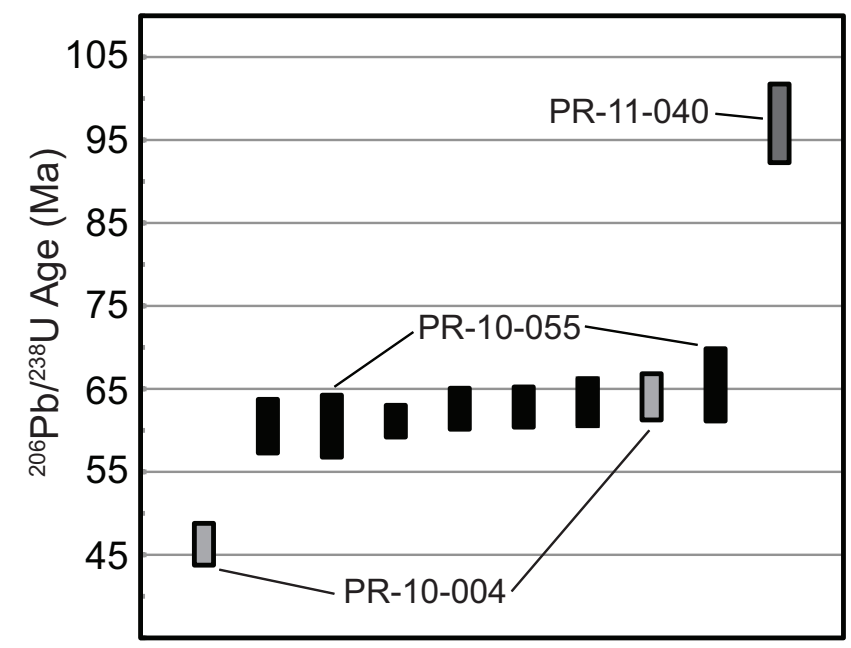

(c) Rathdrum granite (PR-11-005)

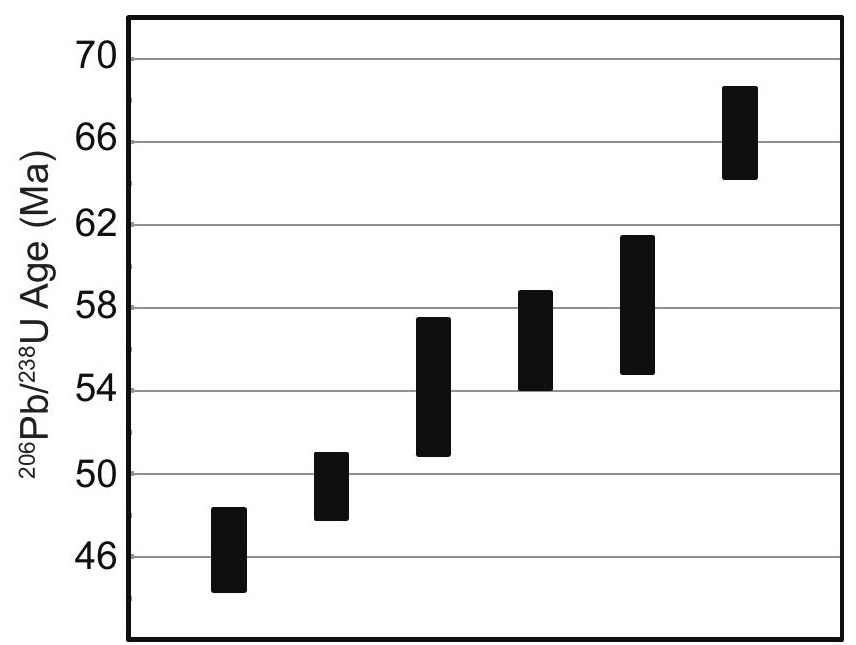

(b) Spokane granite (PR-11-038)

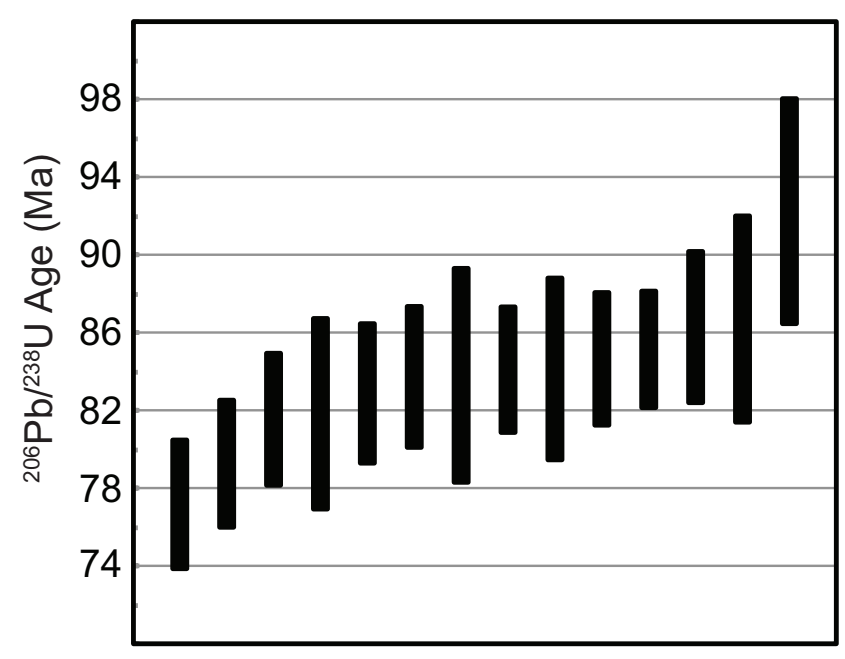

(d) Leucocratic dike (PR-11-014)

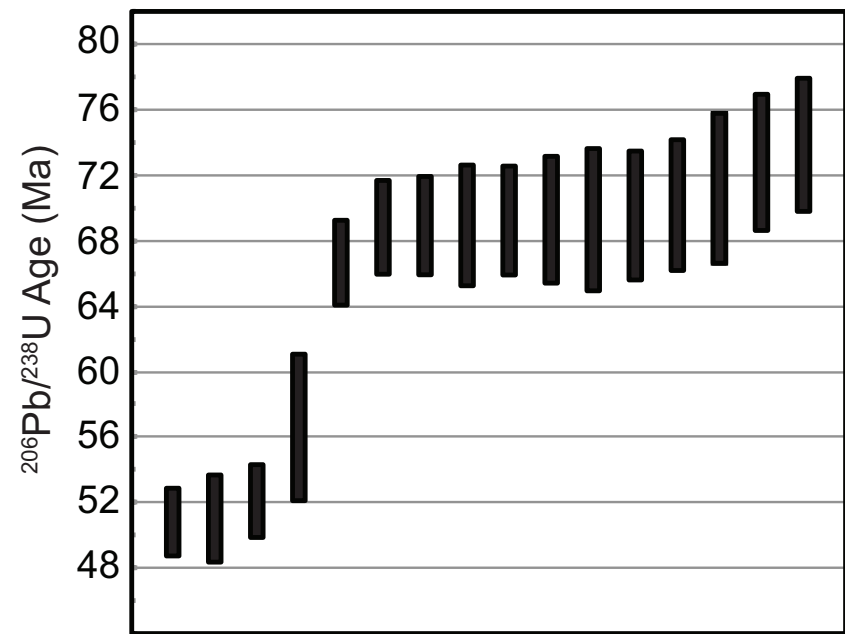


(a) Hauser Lake gneiss

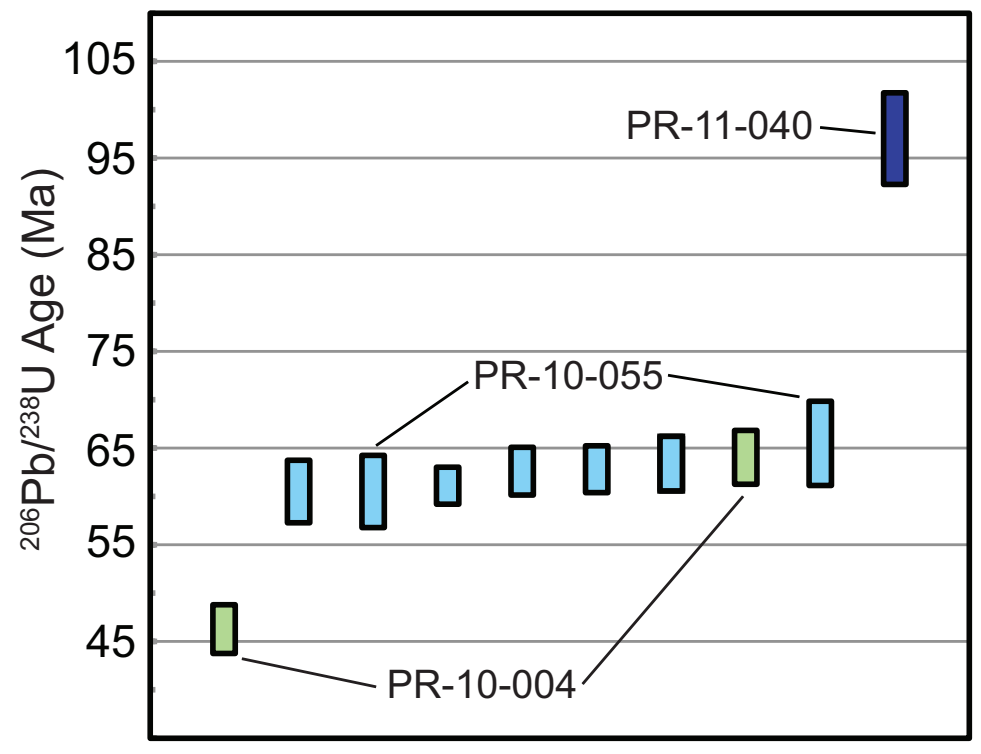

(c) Rathdrum granite (PR-11-005)

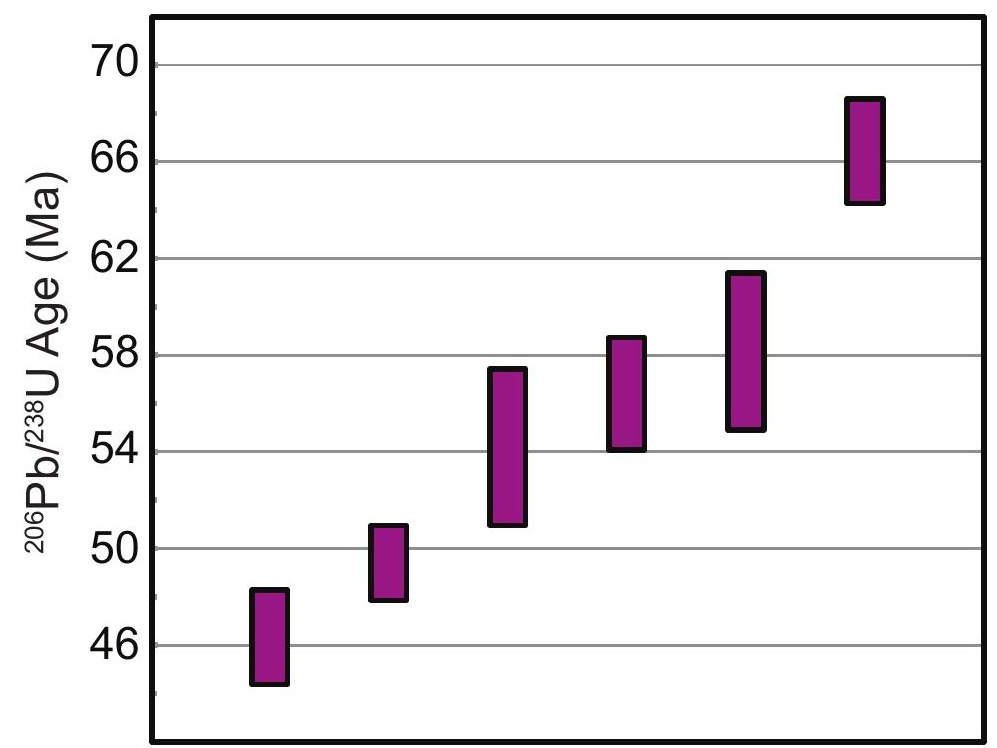

(b) Spokane granite (PR-11-038)

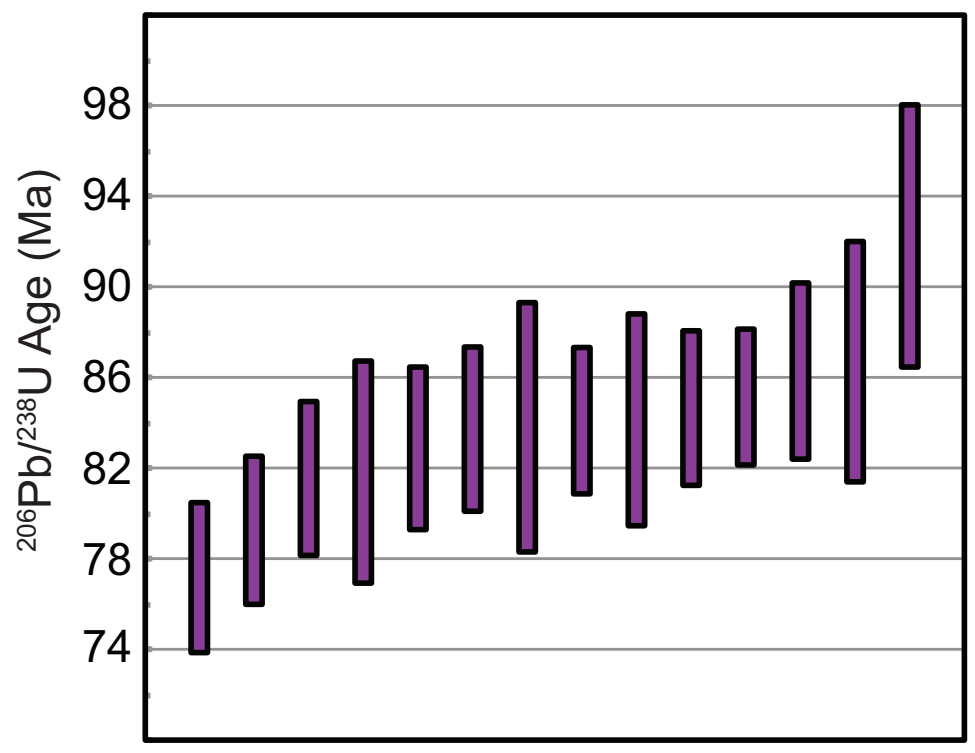

(d) Leucocratic dike (PR-11-014)

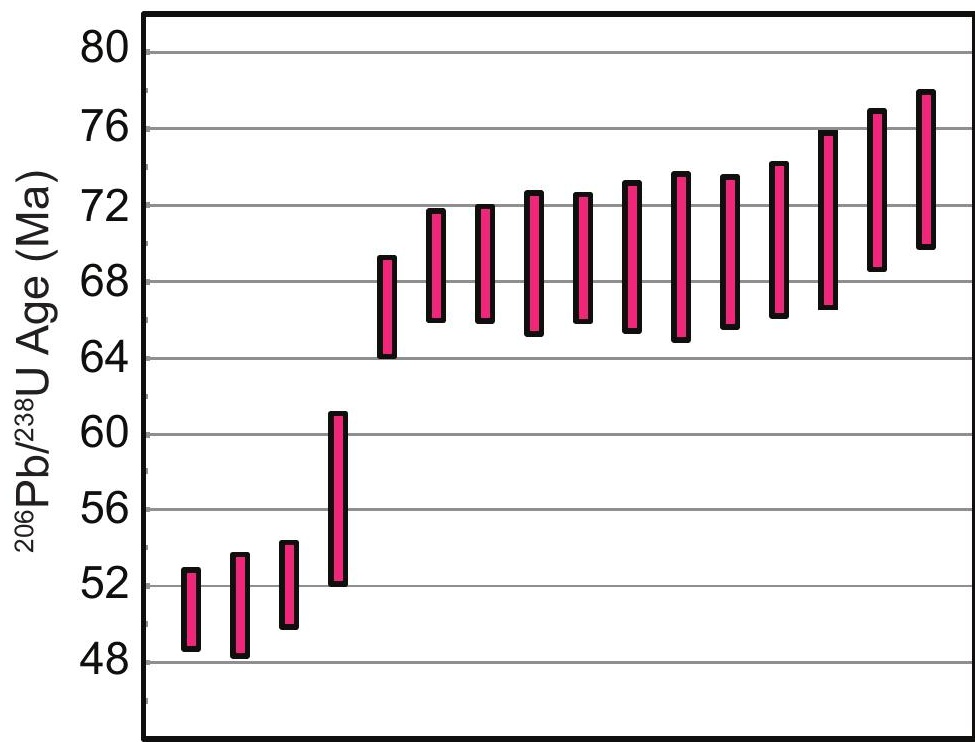


Figure 6

\section{Figure 6 - For Print}

(a)

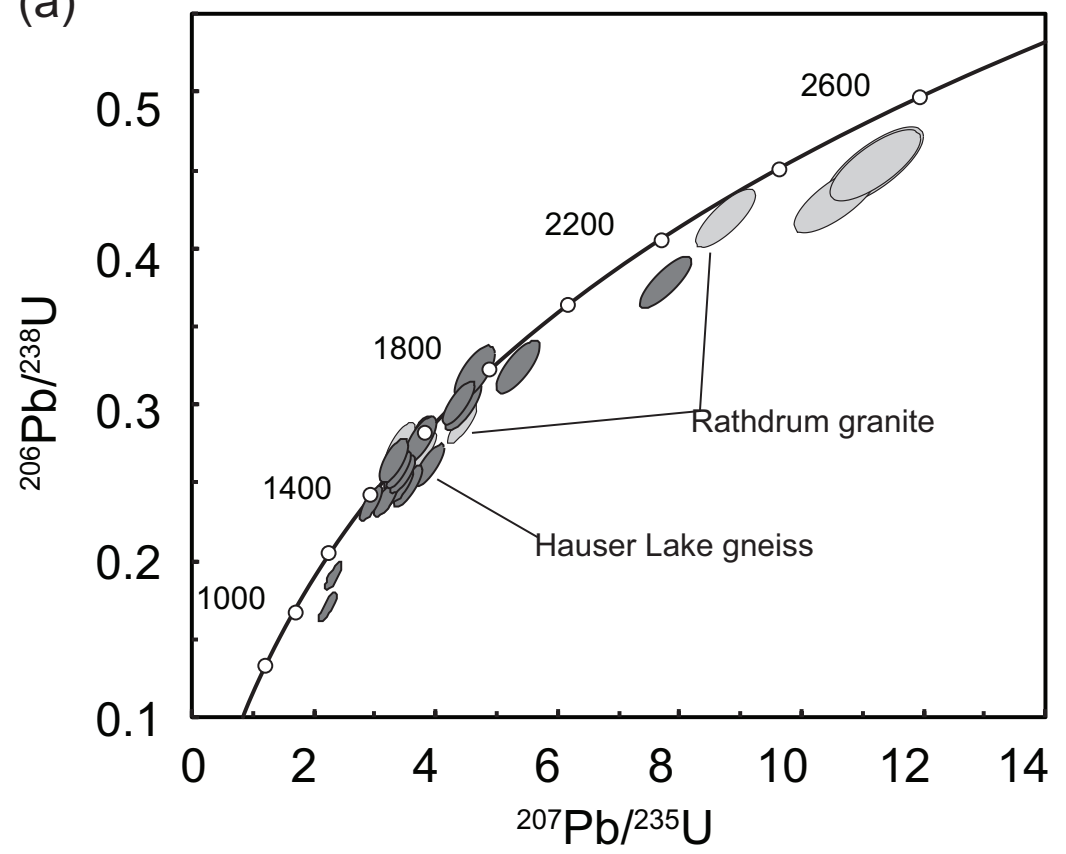

(b)

(b) 20

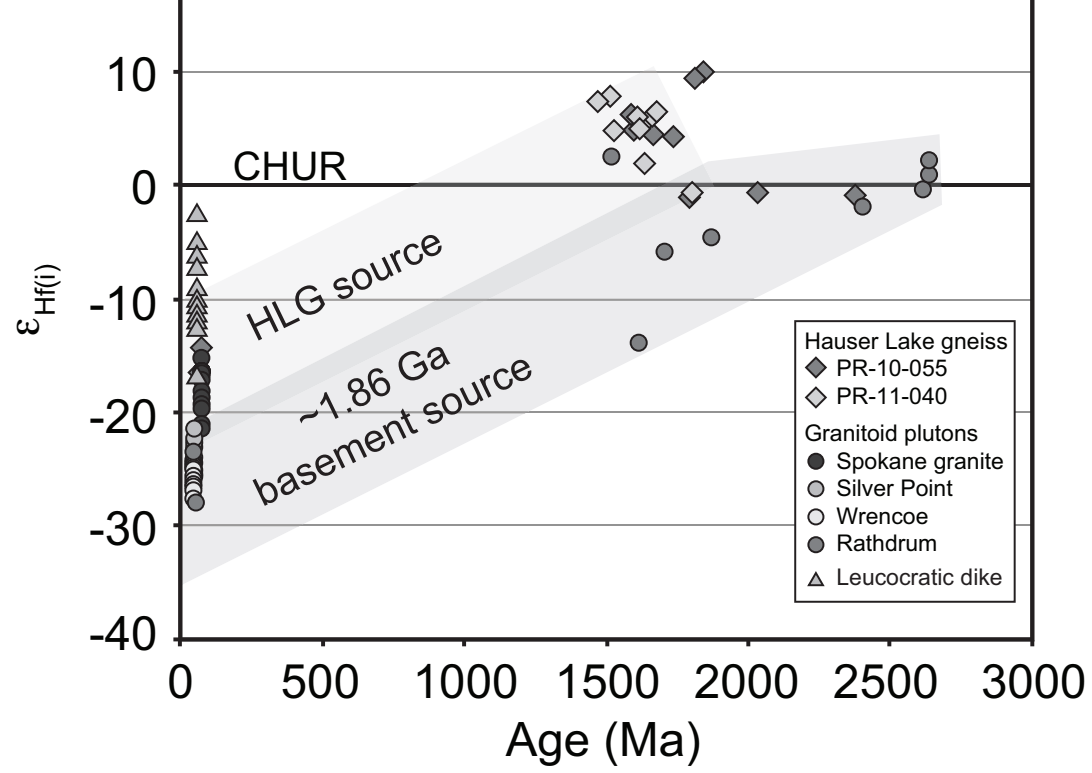

(c)

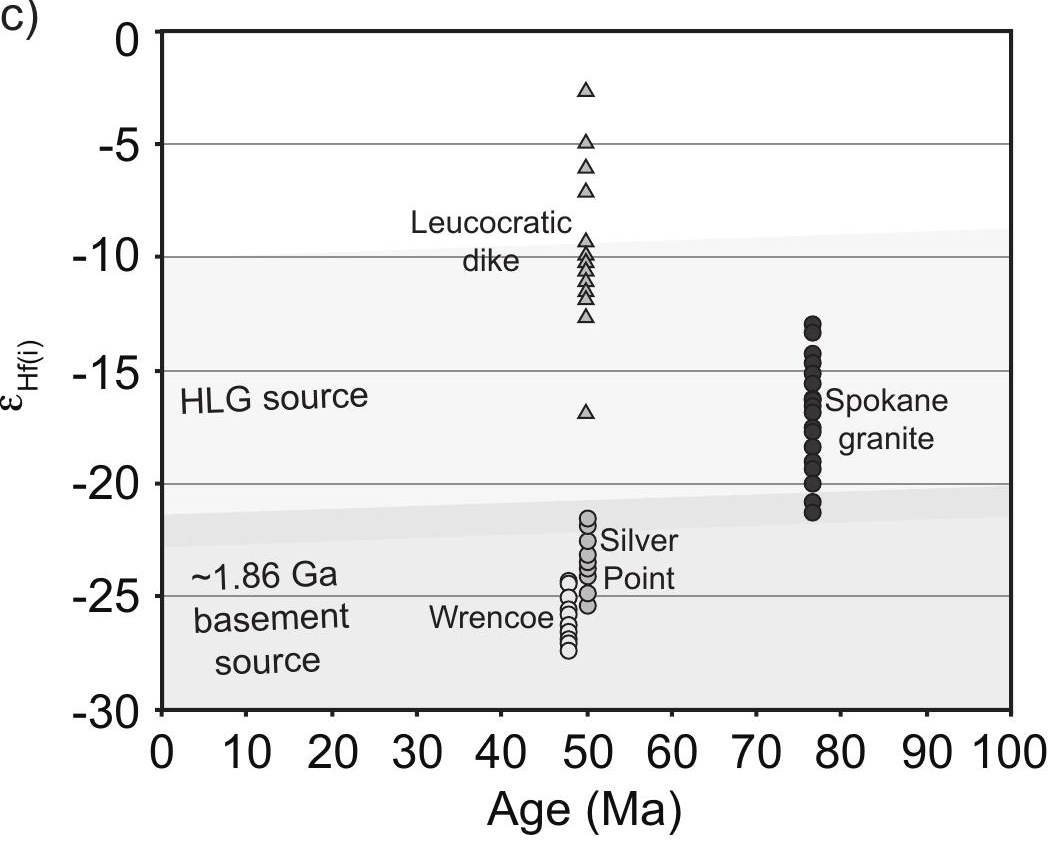


Figure 6 - For Web

(a)

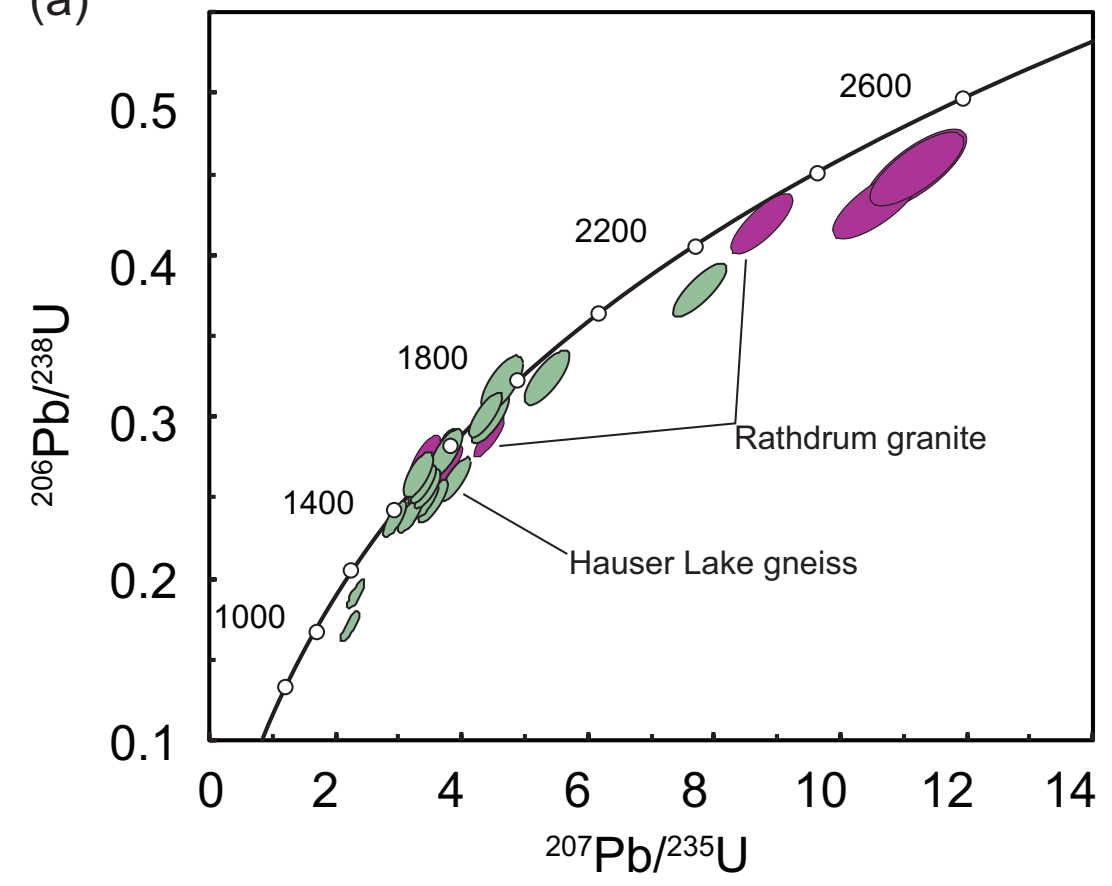

(b)

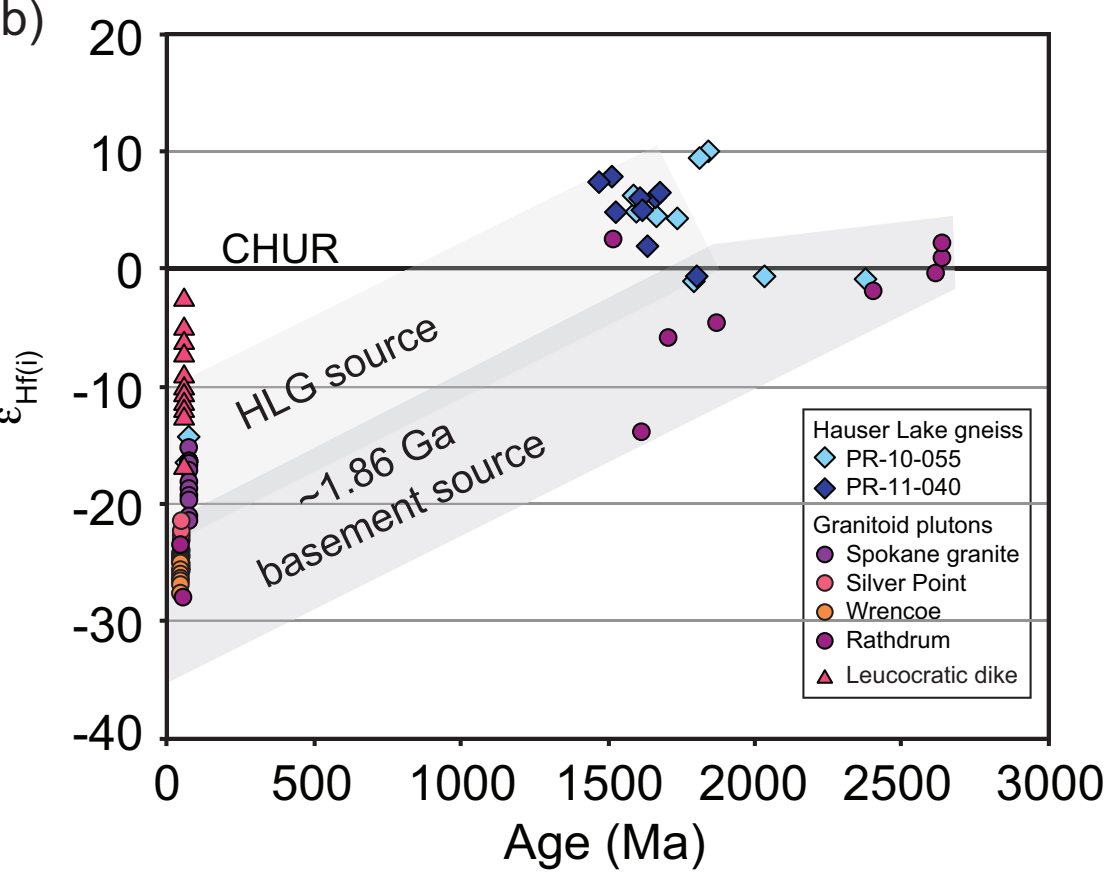

(c)

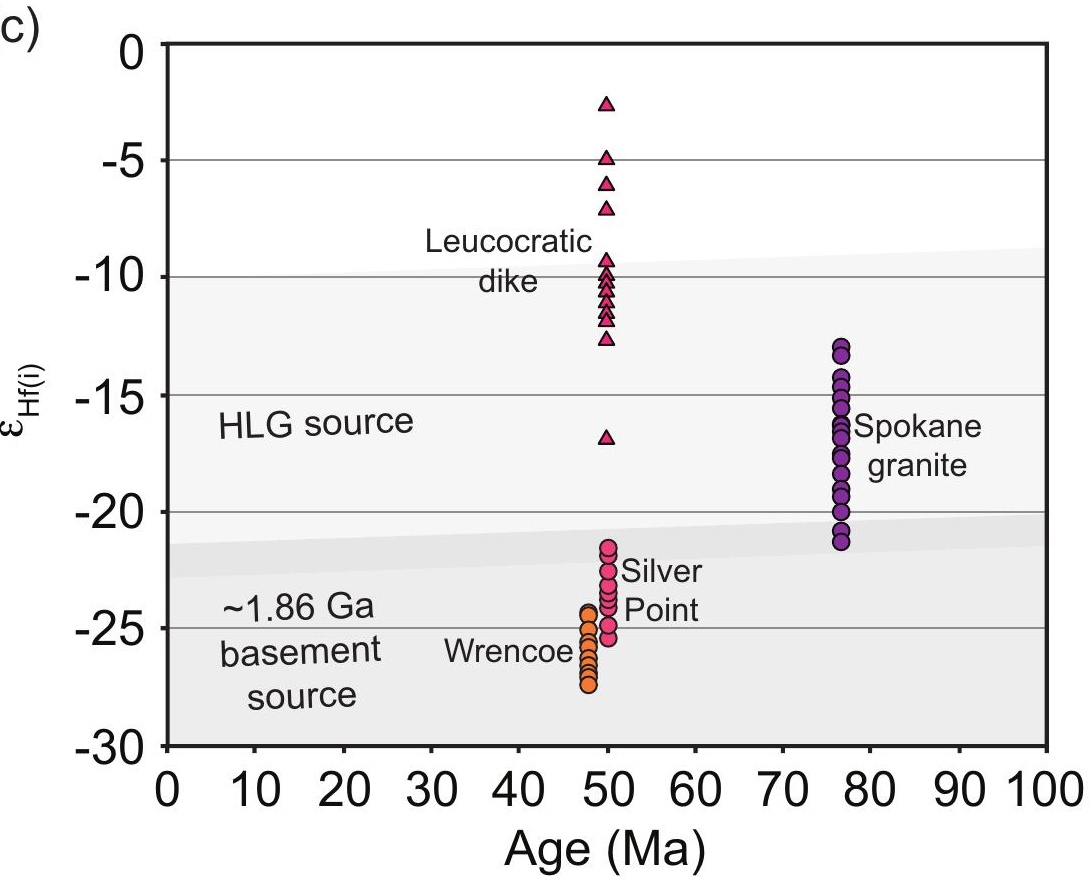


Figure 7

(a)

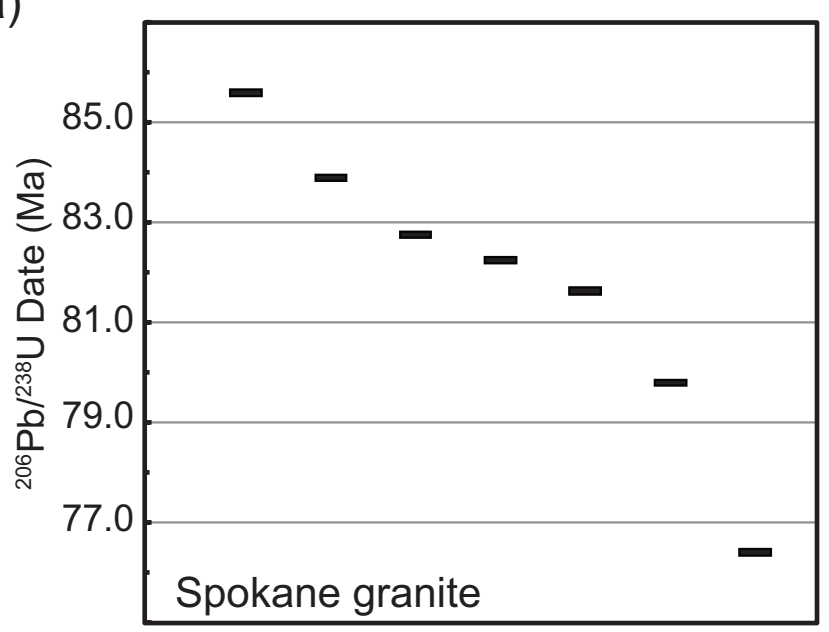

(c)

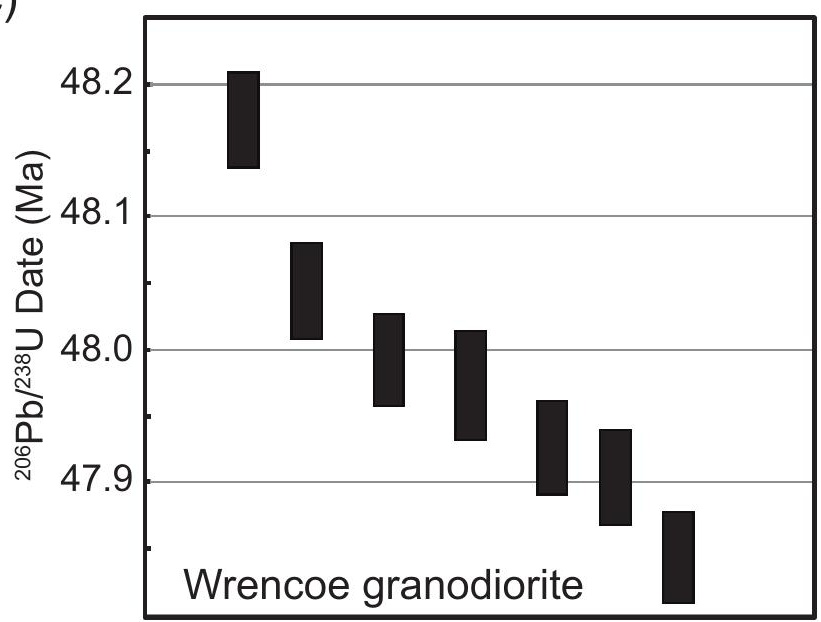

(b)

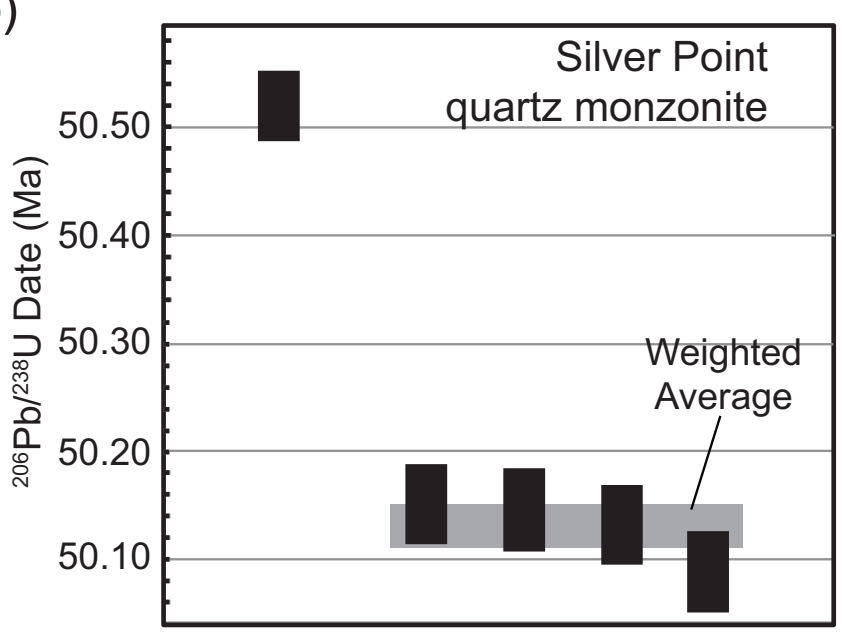

(d)

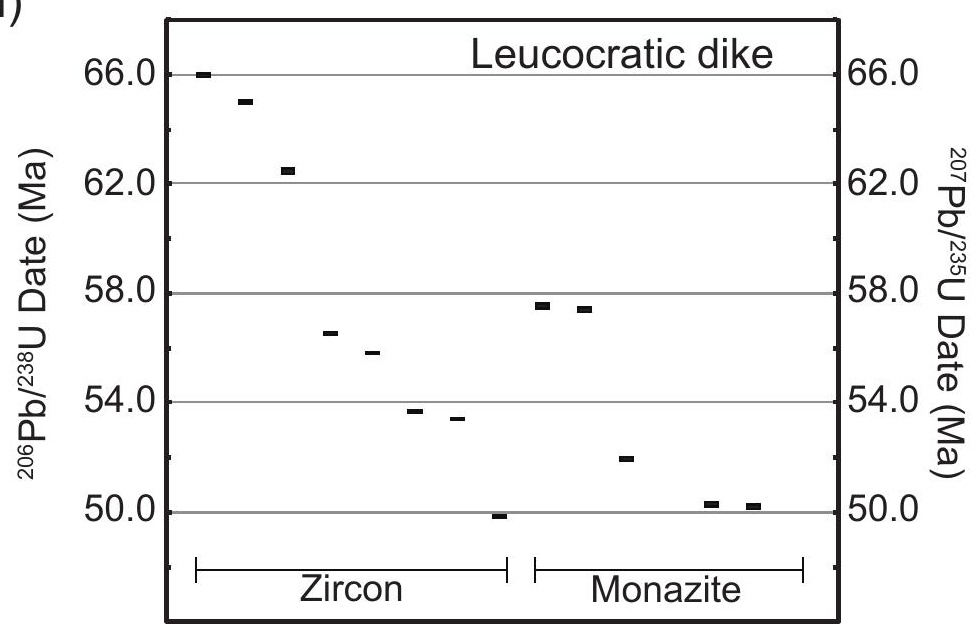


(a)

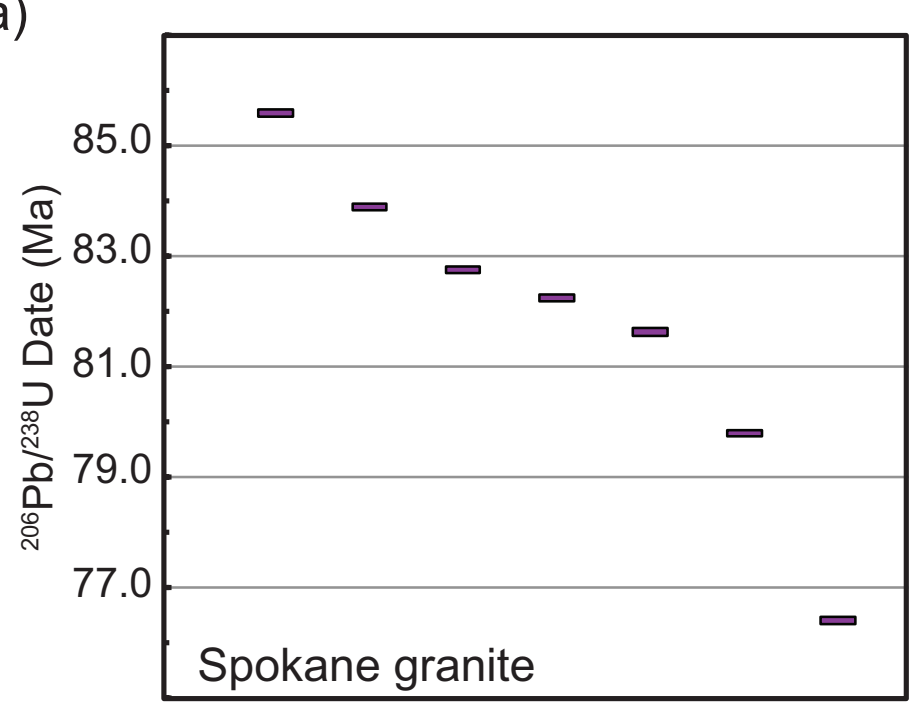

(c)

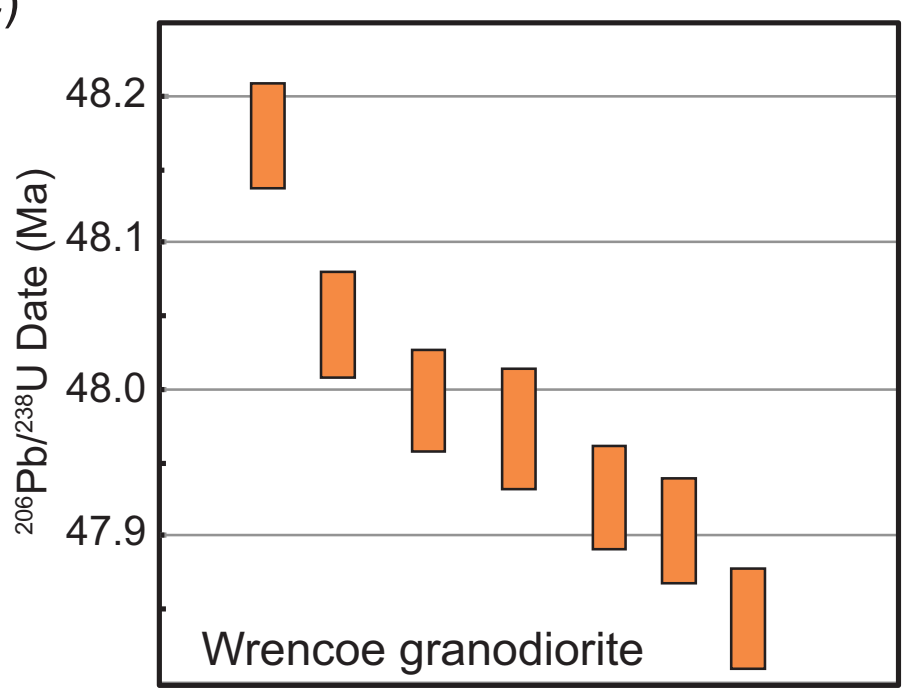

(b)

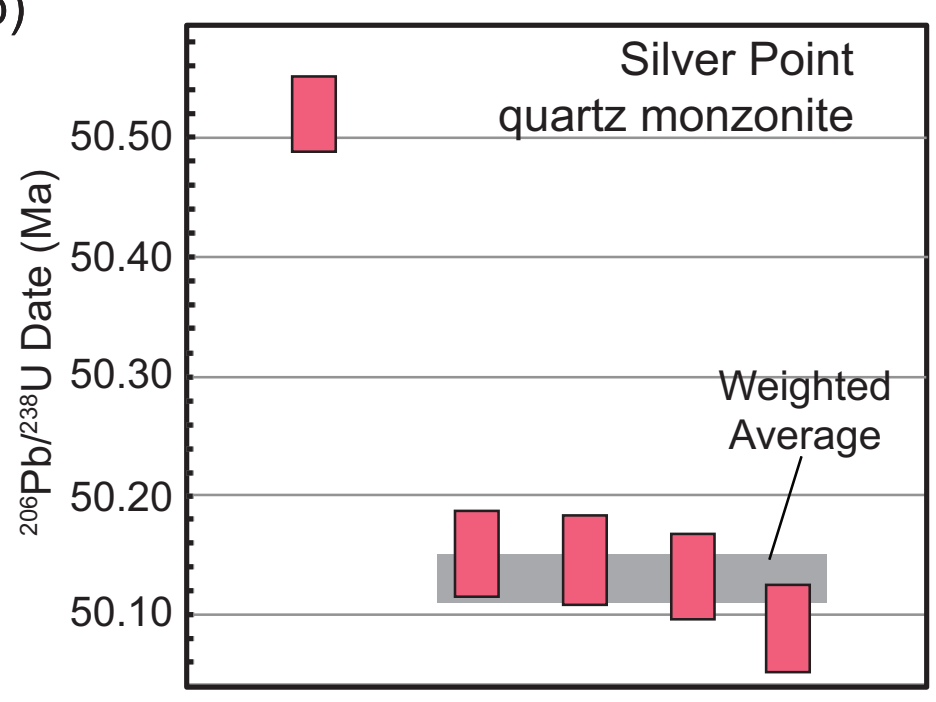

(d)

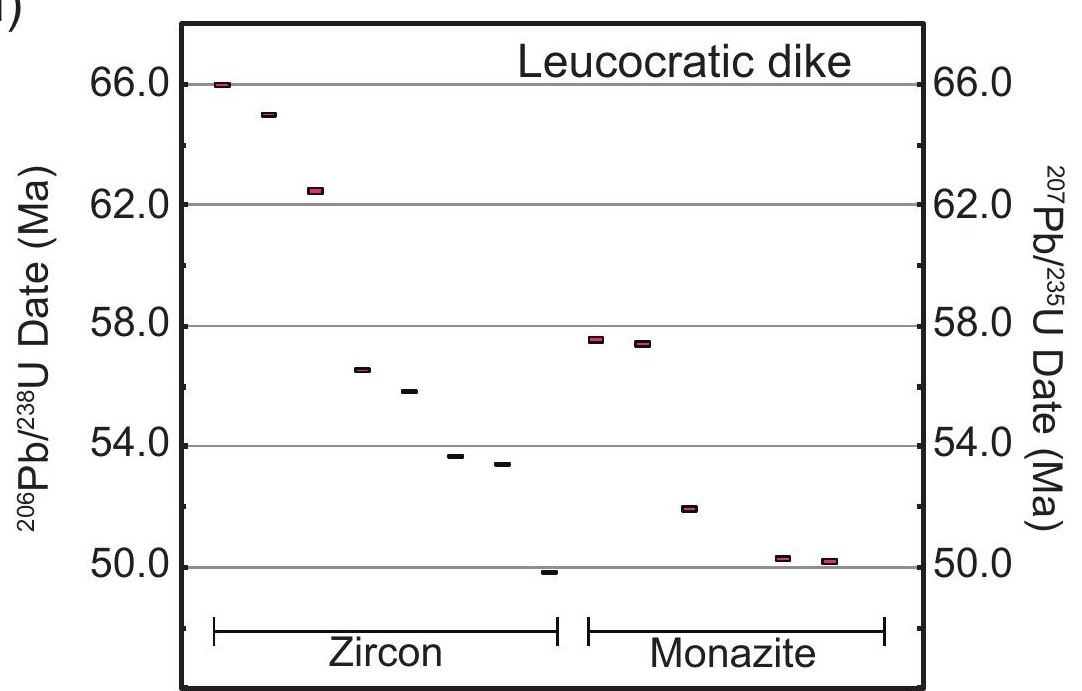


Figure 8 - For Print

(a) c. $76 \mathrm{Ma}$

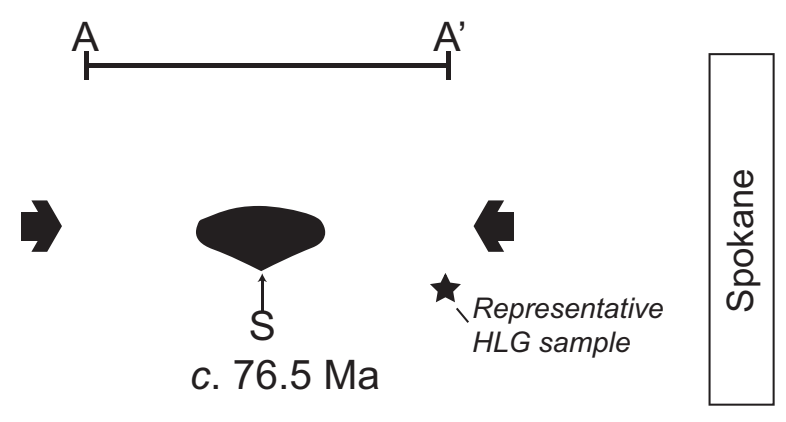

(b) c. $64 \mathrm{Ma}$
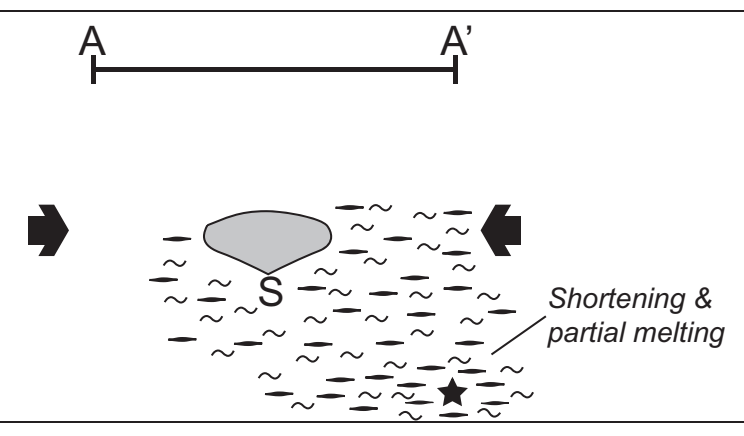

(c) c. $60 \mathrm{Ma}$
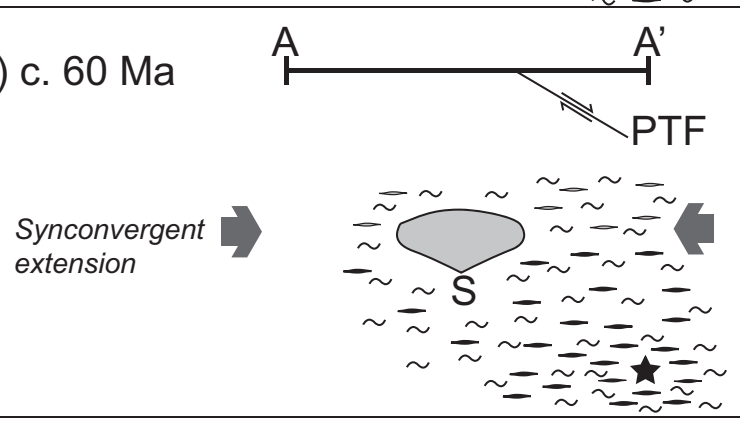

(d) c. $50 \mathrm{Ma}$

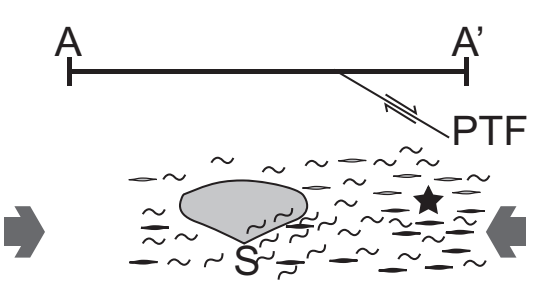

(e) c. $48 \mathrm{Ma}$

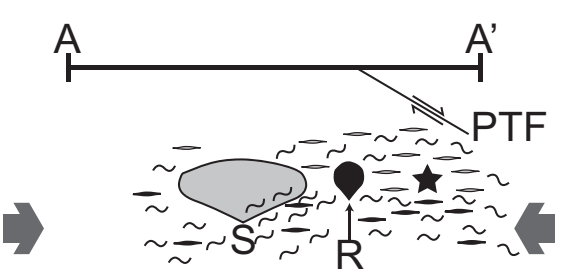

c. $46 \mathrm{Ma}$
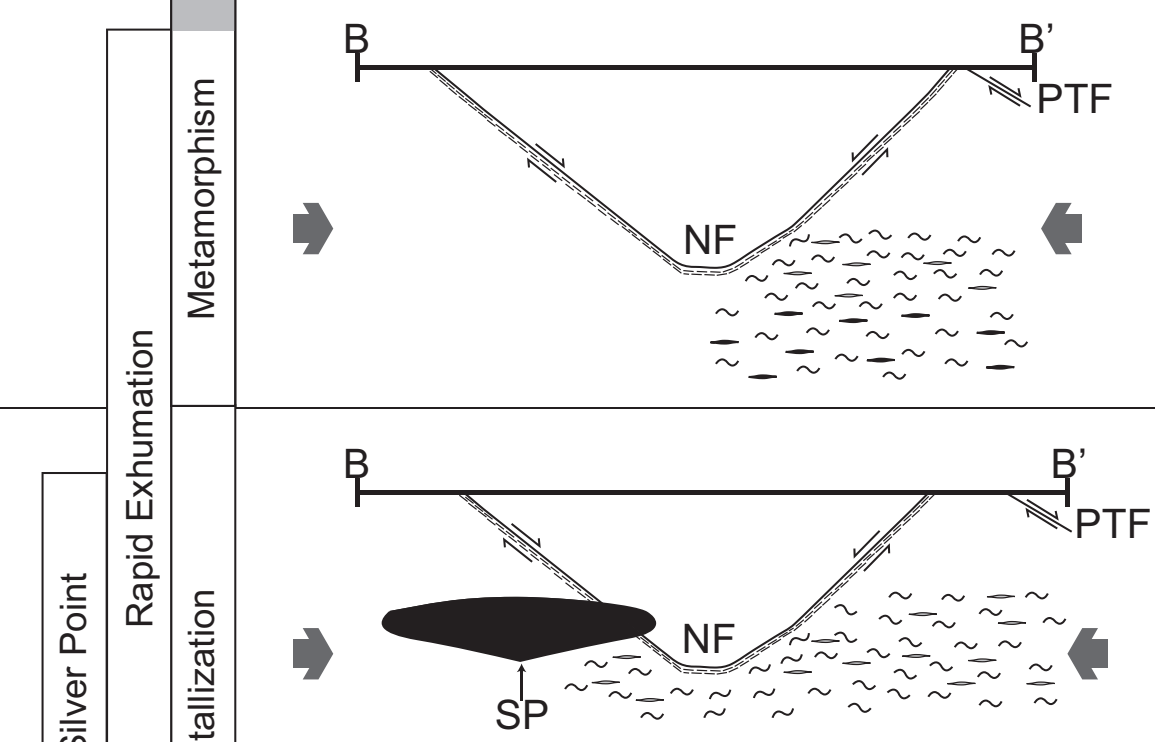

$$
50.13 \pm 0.02 \mathrm{Ma}
$$

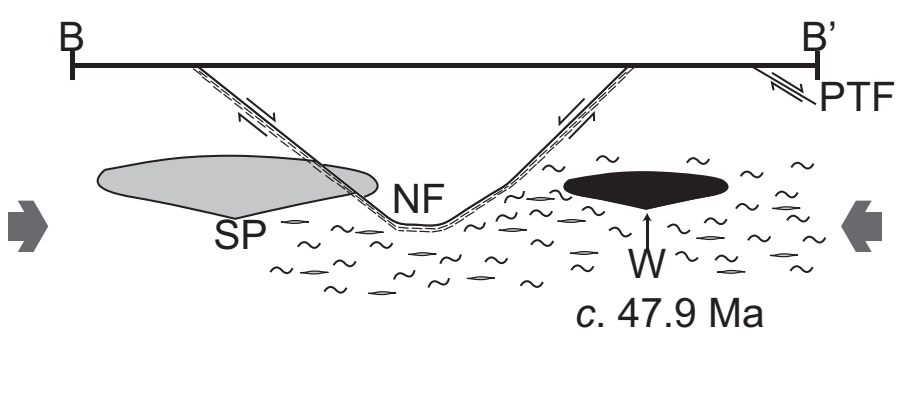

(f) Present
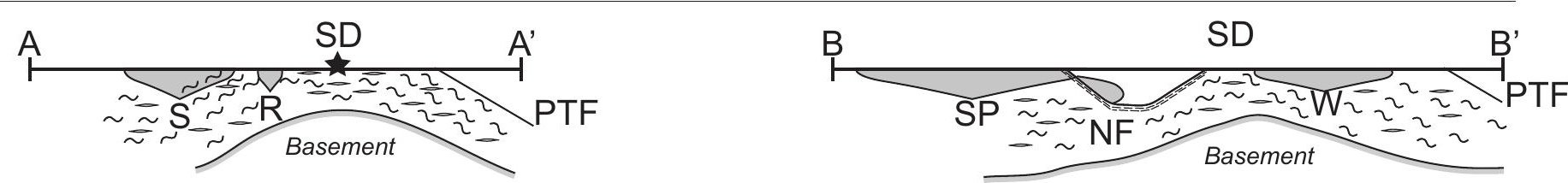
Thor-Odin

Valhalla

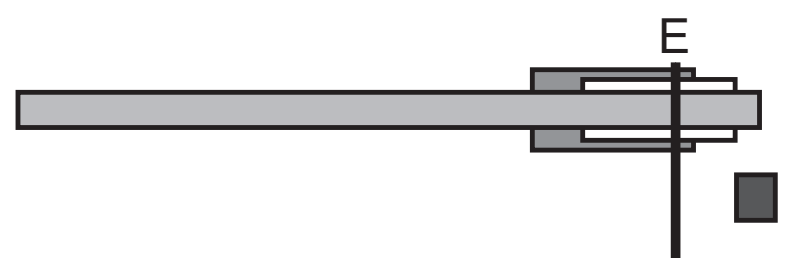

Priest River
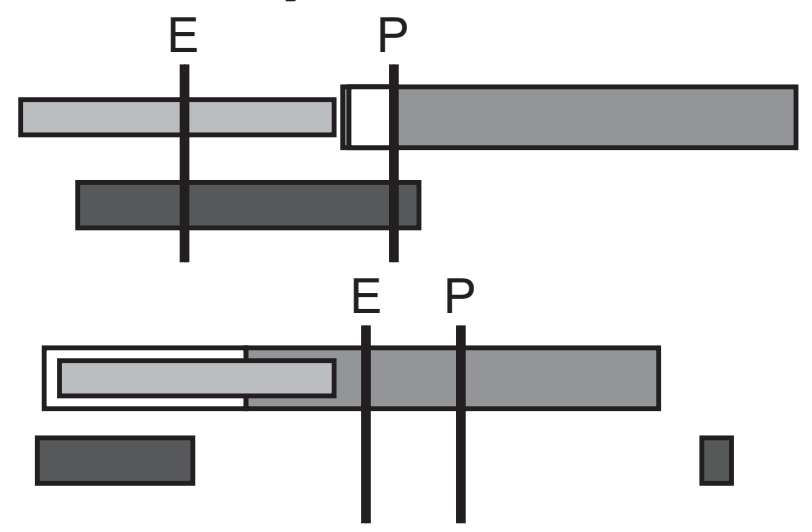

Clearwater
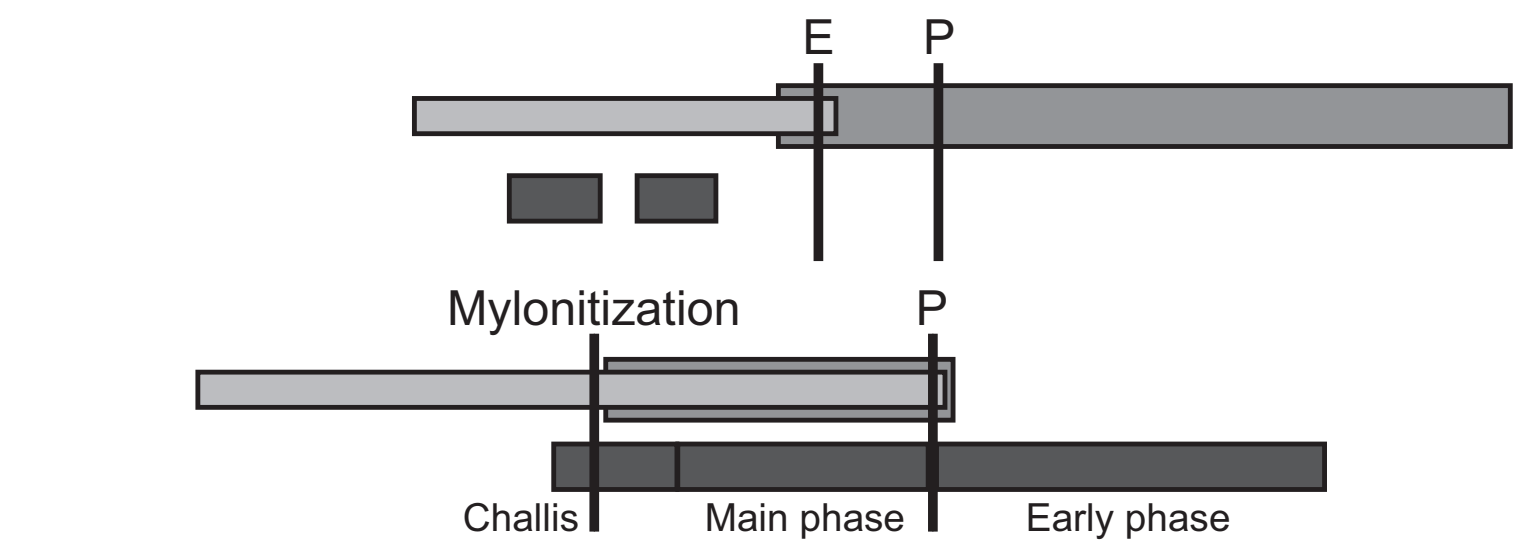

Bitterroot

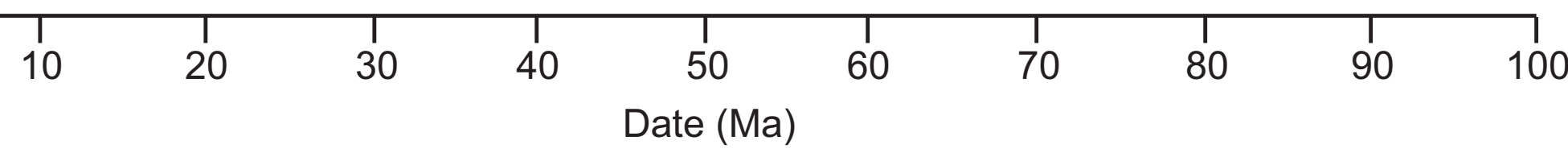

\begin{tabular}{|c|c|c|}
\hline Metamorphism & Leucosome crystallization & Onset of exhumation \\
\hline Pluton crystallization & Cooling & Peak metamorphism \\
\hline
\end{tabular}


Thor-Odin
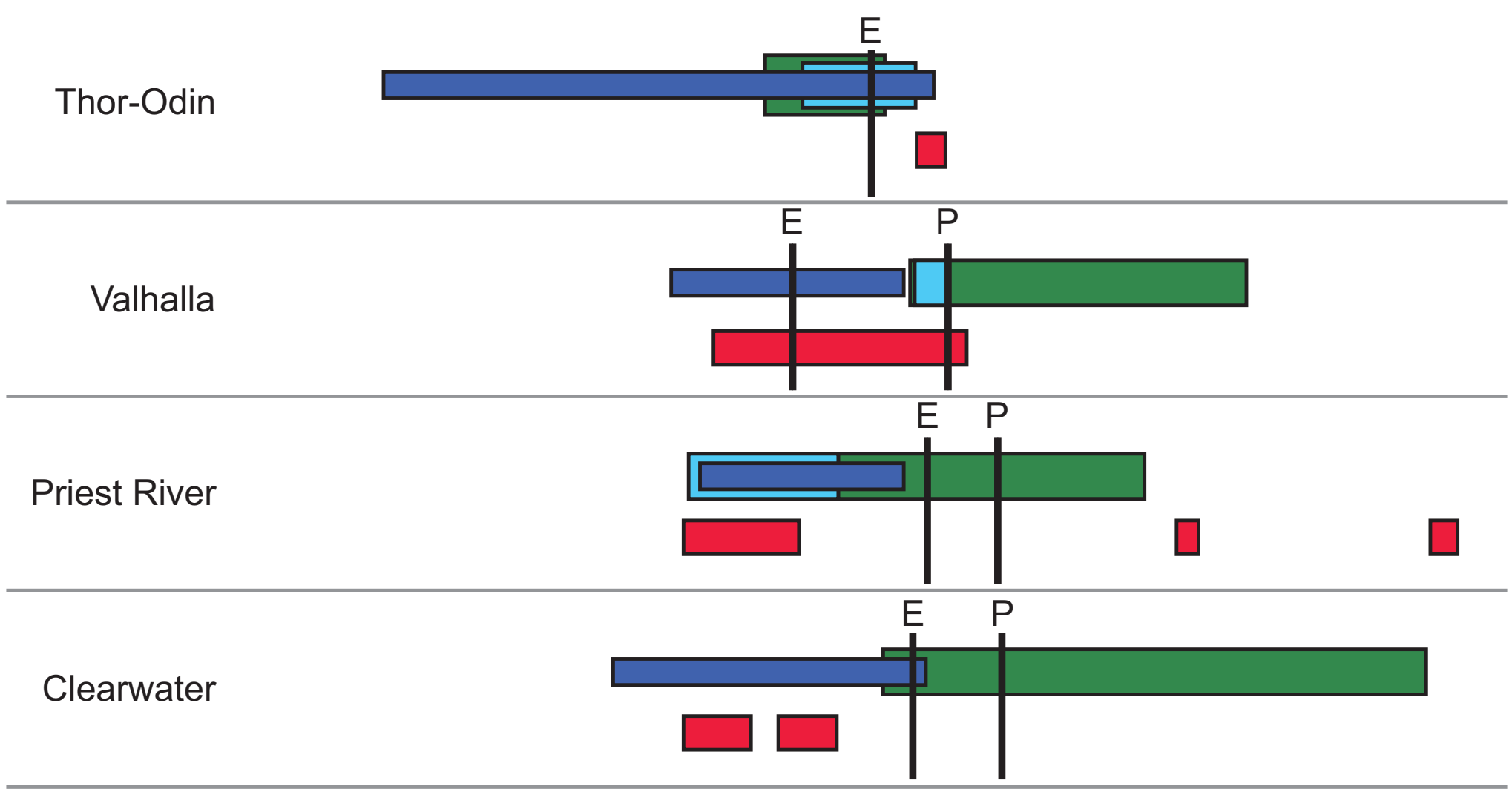

Clearwater

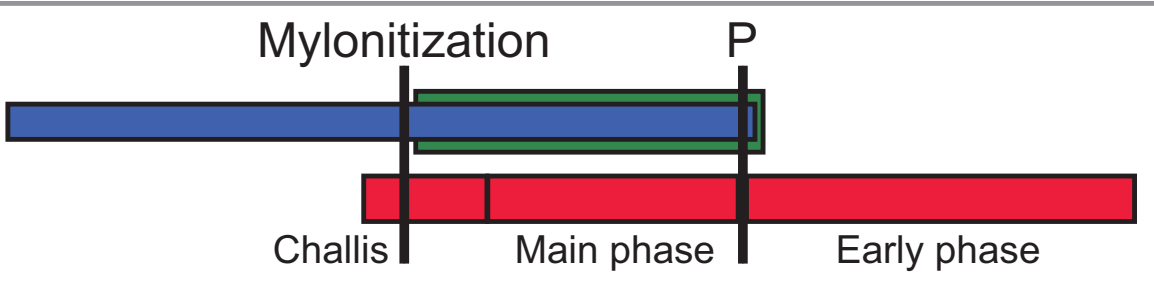

Bitterroot

Metamorphism

Pluton crystallization

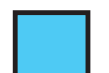

Leucosome crystallization

Cooling
Onset of exhumation

P Peak metamorphism 
Table 1. Samples included in this study.

\begin{tabular}{|c|c|c|c|c|c|c|}
\hline \multirow[b]{2}{*}{ Sample } & \multirow[b]{2}{*}{ Unit } & \multicolumn{2}{|c|}{ Location } & \multicolumn{3}{|c|}{ Analyses } \\
\hline & & Latitude $\left({ }^{\circ} \mathrm{N}\right)$ & Longitude $\left({ }^{\circ} \mathrm{W}\right)$ & LASS-MC-ICPMS & LA-ICPMS & TIMS \\
\hline PR-11-033B & Hauser Lake gneiss & 48.0157 & 117.0057 & $(z)$ & $z$ & \\
\hline PR-10-055 & Hauser Lake gneiss & 48.3102 & 116.8040 & z & z & \\
\hline PR-11-040 & Hauser Lake gneiss & 48.5289 & 116.7557 & z & z & \\
\hline PR-11-038 & Spokane granite & 47.9197 & 117.1101 & z & z & z \\
\hline PR-11-010 & Silver Point quartz monzonite & 48.1191 & 117.2732 & z & & z \\
\hline PR-11-011 & Wrencoe granodiorite & 48.2529 & 116.6116 & $z$ & & $z$ \\
\hline PR-10-043 & Rathdrum granite & 47.9433 & 116.9238 & $z$ & z & \\
\hline PR-11-005 & Rathdrum granite & 47.9598 & 116.9332 & $z$ & $z$ & \\
\hline PR-11-014 & Leucocratic dike & 48.1964 & 116.7199 & z & z & $z, m$ \\
\hline
\end{tabular}

Analyses: LASS-MC-ICPMS for zircon U-Pb geochronology and Hf isotopes; LA-ICPMS for zircon U-Pb geochronology and trace element geochemistry; TIMS for $\mathrm{U}-\mathrm{Pb}$ geochronology.

Abbreviations: $z$ = zircon; $m$ = monazite. Abbreviations are given in ( ) where analysis was unsuccessful. 